FREDERICO DENTELLO

\title{
Análise do conceito de eu em James e Skinner
}

Dissertação apresentada ao Instituto de Psicologia da Universidade de São Paulo, como parte dos requisitos para obtenção do grau de Mestre em Psicologia.

Área de concentração:

Psicologia Experimental

Orientadora:

Profa. Dra. Maria Teresa de Araujo Silva

São Paulo 
Nome: Dentello, Frederico

Título: Análise do conceito de eu em James e Skinner

Dissertação apresentada ao Instituto de Psicologia da Universidade de São Paulo para obtenção do título de Mestre em Psicologia

Aprovado em:

Banca Examinadora

Prof. Dr.

Instituição: Assinatura:

Prof. Dr.

Instituição: Assinatura:

Prof. Dr.

Instituição: Assinatura: 
Ave, Flávia,

jardim ao sol,

lua de verão. 


\section{AGRADECIMENTOS}

Ariocy e Zenaide, pai e mãe, meu coração é seu.

Cristina Carletti e Luiz Maria Veiga, são deliciosos os anos em que trabalhamos juntos e todos os tempos em que discutimos letras, filosofias e ciências variadas, entre livros e gatos, ideias e imaginações.

Maria Teresa de Araujo Silva, querida e modesta professora, no seu nome concentro os bons sentimentos e os grandes aprendizados que tenho vivido na Universidade de São Paulo.

Francisco Marques, poeta giratório, sua amizade é doçura e sua sabedoria é evidente como os brinquedos. Seu incentivo foi essencial em minha trajetória de estudante.

Os membros do Laboratório de Psicofarmacologia do Instituto de Psicologia sempre sustentaram um ambiente fértil para criativos e inovadores debates científicos.

A equipe da Biblioteca Dante Moreira Leite mantém o que para mim sempre foi uma casa de delícias, ponto de encontro privilegiado com a obra de vidas inteiras dedicadas à psicologia.

Maria de Lourdes de Paula, presença frequente enquanto redigia esta dissertação, gentil apoiadora dos meus trabalhos.

O Conselho Nacional de Desenvolvimento Científico e Tecnológico financiou parcialmente esta pesquisa (processo 135093/2006-6). 
Este coração, em mim, posso experimentá-lo e julgo que ele existe. Este mundo, posso tocá-lo e julgo ainda que ele existe. Para aí toda a minha ciência, o resto é construção. Porque, se tento agarrar este eu de que me apodero, se tento defini-lo e sintetizá-lo, ele não é mais do que uma água que corre entre meus dedos. Posso desenhar um por um todos os rostos que ele sabe usar, todos aqueles também que the foram dados, essa educação, essa origem, esse ardor ou esses silêncios, essa grandeza ou essa mesquinhez. Mas não se adicionam rostos. Até este coração que é o meu continuará sendo sempre, para mim, indefinível.

Albert Camus, O mito de Sísifo. 


\section{RESUMO}

Dentello, F. (2009). Análise do conceito de eu em James e Skinner. Dissertação de Mestrado, Instituto de Psicologia, Universidade de São Paulo, São Paulo.

Realizamos um estudo comparativo entre os conceitos de eu tal como formulados pelos psicólogos William James (1842-1910) e B. F. Skinner (1904-1990). No caso de James, a fonte foi o capítulo "A consciência do eu" de sua obra Os princípios de psicologia, a partir do qual relatamos os constituintes do eu empírico, a reflexão do autor sobre o ego puro e a descrição dos sentimentos, emoções e ações do eu. No caso de Skinner, as fontes foram a seção "O indivíduo como um todo" da obra Ciência e comportamento humano e o capítulo "Pensamento" da obra Comportamento verbal, além de alguns outros artigos; discutimos os conceitos de autocontrole e de pensamento conforme o behaviorismo radical, para em seguida definir o eu como um sistema organizado de respostas. Então traduzimos o conceito de eu de James em referências a contingências de reforço: o eu material em termos de filogênese e ontogênese, o eu social em termos de controle de estímulo, o eu espiritual como repertório modelado pela comunidade verbal e o ego puro no contexto dos três níveis de seleção do comportamento humano. Discutimos possíveis influências de James sobre Skinner a partir de relações entre suas teorias psicológicas: a conceituação de eus múltiplos, a rejeição da consciência como substância, a afinidade do empirismo radical com o behaviorismo radical e a ideia de evolução da cultura. Refletimos sobre a atitude de James e Skinner quanto a relacionar dados empíricos a princípios gerais, sobre ambos classificarem a psicologia no conjunto das ciências naturais e sobre as razões de uma suposta morte da psicologia jamesiana e do behaviorismo radical. Finalmente, sugerimos questões para pesquisas posteriores.

Palavras-chave: Análise do comportamento. Autocontrole. B. F. Skinner. Behaviorismo radical. Comportamento verbal. Comunidade verbal. Consciência. Contingências de reforço. Empirismo radical. Eu. Evolução da cultura. Fluxo de pensamento. Pensamento. Subjetividade. William James. 


\begin{abstract}
Dentello, F. (2009). Analysis of the concept of self in James and Skinner. Dissertação de Mestrado, Instituto de Psicologia, Universidade de São Paulo, São Paulo.

This is a comparative study of the concepts of self as formulated by the psychologists William James (1842-1910) and B. F. Skinner (1904-1990). The source for James' concept was the chapter "The consciousness of self" of his book The principles of psychology, from which I described the constituents of the empirical self, the author's reflection on the pure ego, and the feelings, emotions and actions of the self. In Skinner's case, the sources were the section "The individual as a whole" of the book Science and human behavior, the chapter "Thinking" of the book Verbal behavior, and a few other articles; I discussed the concepts of self-control and thinking according to radical behaviorism in order to define the self as an organized system of responses. Then I translated James' concept of self into references to contingencies of reinforcement: the material self in terms of phylogenesis and ontogenesis, the social self in terms of stimulus control, the spiritual self in terms of a repertoire shaped by the verbal community, and the pure ego in terms of the three levels of selection of human behavior. I proposed possible influences of James on Skinner, based on relations between their psychological theories: the conception of multiple selves, the rejection of the conscience as a substance, the affinity of radical empiricism and radical behaviorism, and the idea of evolution of culture. I reflected on the attitude of James and Skinner towards relating empirical data to general principles, on their classification of psychology among the natural sciences, and on the reasons for a supposed death of Jamesian psychology and radical behaviorism. Finally, I suggested some questions to further investigations.
\end{abstract}

Keywords: B. F. Skinner. Behavior analysis. Consciousness. Contingencies of reinforcement. Evolution of culture. Radical behaviorism. Radical empiricism. Self. Self-control. Stream of thought. Subjectivity. Thinking. Verbal behavior. Verbal community. William James. 


\section{SUMÁRIO}

1. INTRODUÇÃO

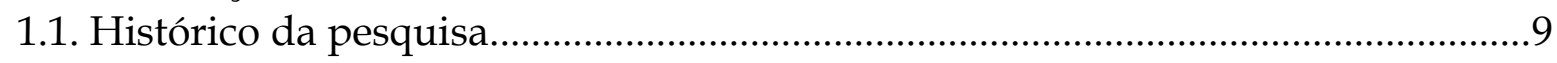

1.2. Objeto da pesquisa....................................................................................13

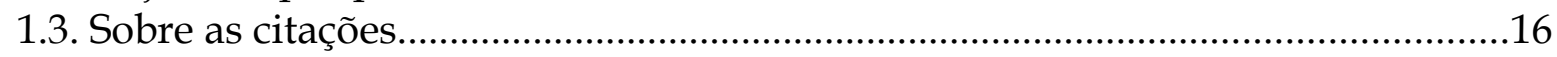

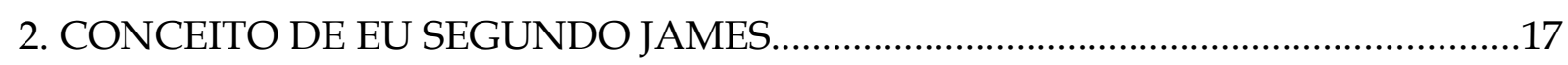

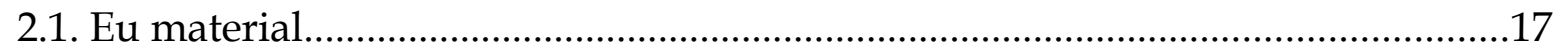

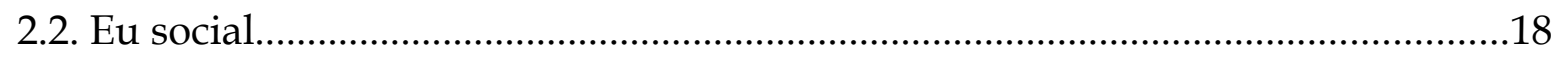

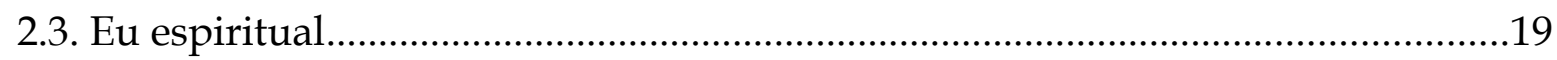

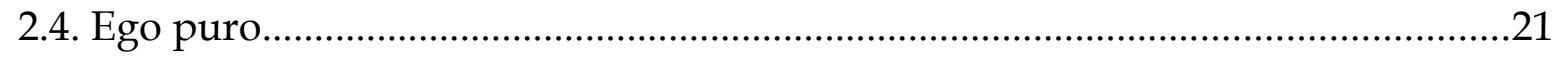

2.5. Sentimentos e emoções suscitados pelo eu..............................................................24

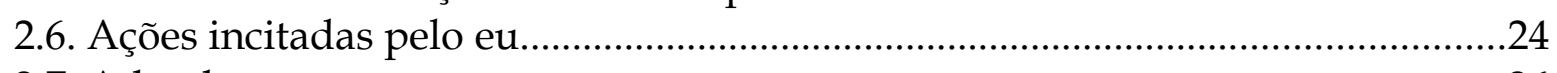

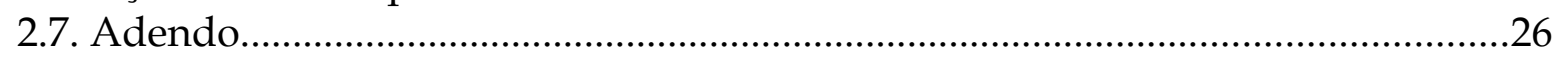

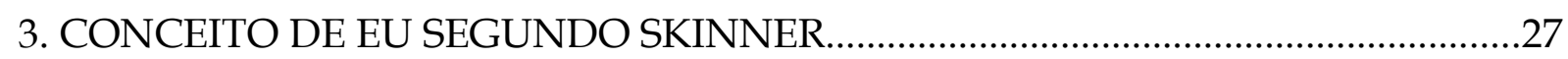

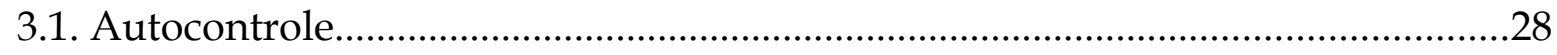

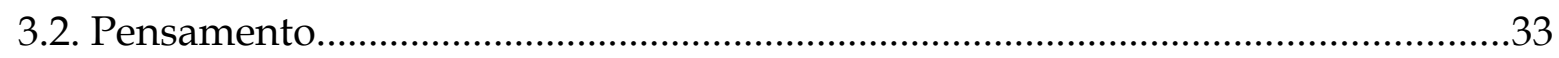

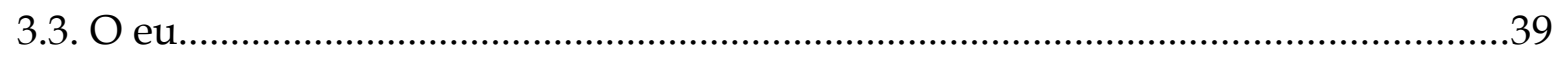

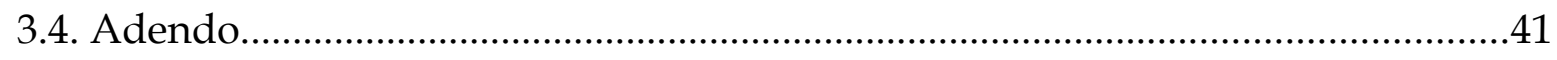

4. TRADUÇÃO DO CONCEITO DE EU...................................................................42

4.1. Eu material, filogênese e ontogênese.....................................................................43

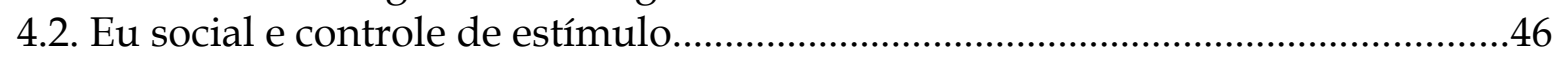

4.3. Eu espiritual e comunidade verbal......................................................................52

4.4. Ego puro e três níveis de seleção.........................................................................57

4.5. Sentimentos, emoções e ações do eu........................................................................59

5. JAMES E SKINNER: HEREDITARIEDADE E MUTAÇÃO...........................................62

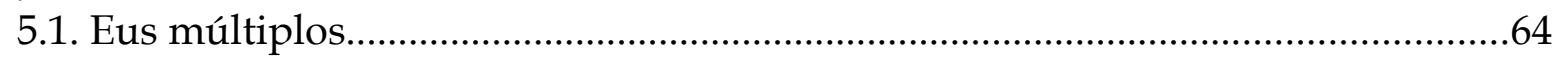

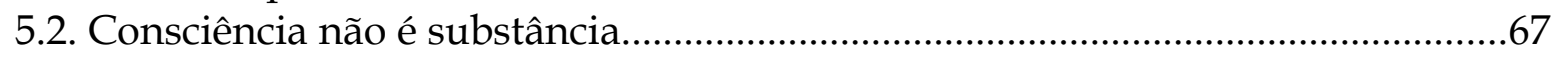

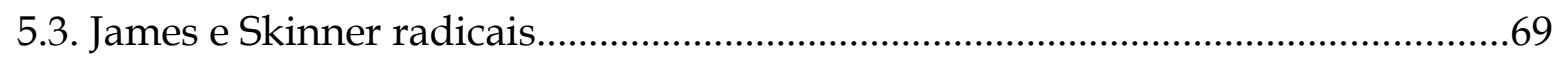

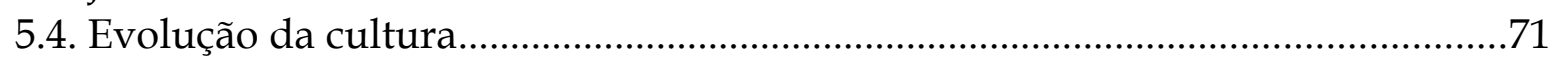

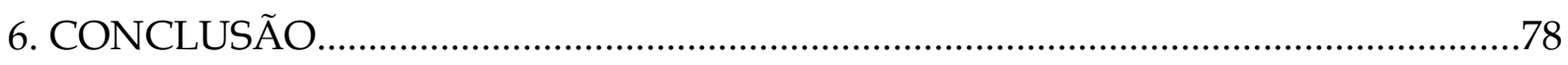

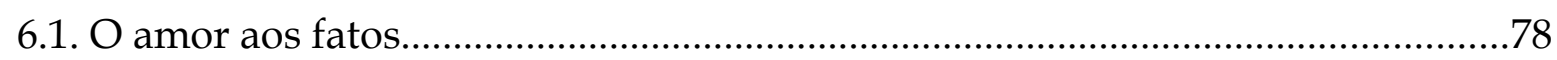

6.2. A psicologia e as outras ciências naturais.................................................................

6.3. A suposta morte da psicologia jamesiana................................................................82

6.4. Questões para possíveis investigações posteriores....................................................84

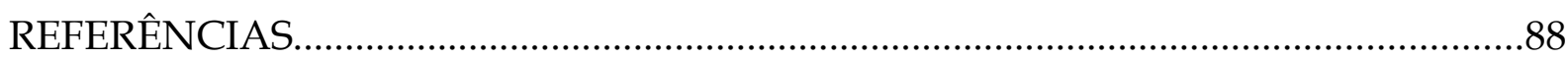




\section{INTRODUÇÃO}

\subsection{Histórico da pesquisa}

A pesquisa que resultou nesta dissertação passou por significativas mudanças de rumo ao longo de seu desenvolvimento, e queremos começar nossos argumentos com um relato dessa trajetória. Vale ressaltar, no entanto, que um tema se manteve presente desde o início: o conceito de $e u$.

Nosso projeto inicial de pesquisa pretendia investigar o eu entendido como o agente interior que causaria ou originaria tanto as ações públicas do indivíduo quanto suas atividades psicológicas. Essa é uma suposição básica das explicações leigas dos fenômenos psicológicos e ao mesmo tempo é um dos fundamentos de variadas teorias tradicionais. Pretendíamos fazer um apanhado das formas que o conceito de eu assume em algumas teorias psicológicas, assim como enunciá-lo em termos behavioristas, através de referências a contingências de reforço. Especificamente, nossa intenção era identificar maneiras de descrever o eu no campo do comportamento verbal, a partir do que pudéssemos extrair de Skinner (1957), com uma argumentação centrada no reforço socialmente mediado. A pretensão final era

sugerir definições operacionais que permitissem pesquisas posteriores da subjetividade em laboratório.

Logo ficou claro que tal projeto exigiria mais tempo e investigações do que os disponíveis para uma pesquisa de mestrado. Para realizar uma coletânea dos modos como o conceito de eu é usado em diferentes escolas psicológicas na figura de um agente criador, por exemplo, de modo que esse relato pudesse acrescentar algo aos argumentos de Skinner $(1953,1974)$, teríamos de percorrer um grande número de textos de várias psicologias, o que, além de ser uma tarefa demorada, dificilmente resultaria em dados úteis ou de interesse para uma pesquisa que nunca pretendeu ser de história da psicologia. Ademais, embora continue interessante, em nossa opinião, identificar na obra Comportamento verbal (Skinner, 1957) uma teoria específica sobre o eu, o esforço interpretativo requerido para executar essa tarefa 
ultrapassaria os limites impostos a uma pesquisa de mestrado - ou, por outro lado, talvez acabasse por excluir o tema inicial de pesquisa, se nos concentrássemos na principal pista que há no livro a respeito do papel do eu no comportamento verbal: os autoclíticos (Skinner, 1957, cap. 12). Quanto à pretensão de propor definições operacionais de fenômenos subjetivos para estudo em laboratório, senão uma ambição irrealista, significaria em nossa opinião o mesmo que pesquisar eventos comportamentais por meio de referências a outros comportamentos e não às condições que os determinam.

Deste modo, passamos a buscar um objeto de pesquisa mais adequado diante das condições dadas. Como contraponto à análise do comportamento e o behaviorismo radical no debate sobre o conceito de eu, ao invés de investigar todas as outras escolas psicológicas, ponderamos limitar o estudo a somente uma formulação teórica. Assim, consideramos em seguida usar como conceito contrastante o que decorre das proposições de Turing (1950) para a psicologia e, em particular, para uma teoria da subjetividade. A ideia era investigar o que poderia ser descrito como um conceito de eu a partir do teste proposto pelo cientista para decidir se uma entidade pensa, tem consciência, ou é inteligente. Resumidamente, o teste de Turing fundamenta-se num critério de indistinguibilidade e é assim executado: um indivíduo, isolado numa sala, envia perguntas a dois entes que estão em outras salas, e deles recebe respostas; um deles é um ser humano e o outro é um computador. Após algumas rodadas de perguntas e respostas, o indivíduo deve julgar quem é o ser humano e quem é a máquina. Depois de um certo número de repetições desse jogo, se o interrogador acerta seus julgamentos tão frequentemente quanto erra, o ser humano e a máquina respondentes são declarados indistinguíveis, e disso decorreria que a máquina pensa, é inteligente, ou tem consciência. Se esse é um critério objetivo para a definição de consciência individual de um ente singular, por que não derivar dele um conceito de eu?

A enunciação de um conceito de eu a partir do teste de Turing parecia frutífera à medida que envolveria procedimentos objetivos, empiricamente isoláveis e passíveis de serem executados praticamente. Além disso, havia a vantagem de a interação entre os indivíduos do teste ser uma troca de perguntas e respostas, que 
poderia portanto ser formalmente tratada como uma série de episódios verbais - o que nos aproximaria de uma análise decorrente das ideias apresentadas por Skinner (1957). Ao dar os primeiros passos nessa direção, entretanto, percebemos que outra vez nos afastaríamos tanto dos limites impostos à extensão de uma pesquisa de mestrado quanto dos interesses específicos da psicologia. Teríamos de enveredar pela ciência da computação, por exemplo, e sobretudo por argumentos filosóficos, a fim de estabelecer um território em comum no qual o debate entre psicologia e informática sobre o conceito de eu pudesse ser desenvolvido. O próprio Turing deixara claro que seu interesse estava centrado nas possibilidades de construção de computadores úteis e não na ampliação do conhecimento sobre os fenômenos psicológicos. Então, novamente alteramos o rumo de nossas pesquisas, tendo em mente o que Skinner (1974, p. 110) afirmou no fim de uma crítica à atitude de entender a psicologia a partir do funcionamento dos computadores: "Por falar nisso, não é o behaviorista, mas o psicólogo cognitivo, com seu modelo da mente como um computador, quem representa o homem como uma máquina".

Antes de prosseguir, uma última consideração a esse respeito: as ideias de Turing continuam um campo fecundo para a imaginação dos pesquisadores. Alguns dos experimentos realizados por Neuringer, Jensen e Piff (2007), por exemplo, incidentalmente exploraram o critério de indistinguibilidade proposto por Turing na investigação do que se entende como escolhas tipicamente humanas - nesses experimentos, indivíduos deviam observar os desempenhos de participantes desconhecidos num jogo; os desempenhos eram produzidos através de algoritmos, isto é, nenhum dos "jogadores" era um ser humano; e os desempenhos produzidos a partir de leis de distribuição de respostas empiricamente determinadas através da análise experimental do comportamento eram consistentemente declarados como provenientes da ação de seres humanos. O computador, então, sob as condições particulares desse jogo, passou no teste de Turing quando programado segundo leis obtidas por meio da análise do comportamento de organismos vivos - não necessariamente humanos.

Enquanto buscávamos alternativas para o teste de Turing como objeto de pesquisa, começamos a ler Os princípios de psicologia de James (1890) de maneira algo 
informal, mas ao mesmo tempo como uma possível fonte para o que denominaríamos teorias tradicionais em psicologia, a serem usadas como referência para relacionar os conceitos derivados da análise do comportamento ao campo psicológico em geral. A leitura foi uma surpresa para nós; rapidamente percebemos que a obra seria mais do que apenas uma representante de teorias tradicionais em psicologia. Encontramos ali uma afinidade fascinante com o programa do behaviorismo radical para uma ciência do comportamento humano. Dois elementos do pensamento jamesiano foram especialmente relevantes para nossos interesses: James (1890) concebe a psicologia como uma ciência natural, isto é, seus objetos e métodos de produção devem ser compatíveis com a categoria de fenômenos com os quais as outras ciências naturais se ocupam e como os investigam; e ele rejeita a suposição de haver um agente interior que causa ou origina as atividades psicológicas - em outras palavras, justamente a fim de garantir que a psicologia seja válida como ciência, ela deve ser distinguida de uma filosofia psicológica ou de uma psicologia filosófica, e a esse respeito ele declara já no prefácio: “Todas as tentativas de explicar nossos pensamentos fenomenalmente dados como produtos de entidades profundas (sejam elas chamadas 'Alma', 'Ego Transcendental', 'Ideias' ou 'Unidades Elementares de Consciência') são metafísicas" (James, 1890, p. xiii). É importante deixar claro que James ter qualificado como metafísicas as tentativas de explicação a que ele se refere não quer dizer que despreze a filosofia. Ele aponta ali e em todo o seu livro a importância de que a psicologia, uma vez que é ciência, proceda cientificamente. A ideia fica mais clara na seguinte declaração:

Metafísica não significa nada senão um esforço inusualmente obstinado para pensar claramente. As concepções fundamentais da psicologia são muito claras para nós praticamente, mas teoricamente são muito confusas, e facilmente fazem-se nessa ciência as mais obscuras suposições sem perceber-se, até serem desafiadas, quais dificuldades internas elas envolvem. Quando essas suposições uma vez se estabeleceram... é quase impossível livrar-se delas depois ou fazer alguém ver que elas não são elementos essenciais da investigação (James, 1890, p. 95). 


\subsection{Objeto da pesquisa}

Atravessado o percurso que descrevemos na seção anterior, escolhemos como objeto para comparar com o conceito de eu em Skinner aquele formulado por James no capítulo "A consciência do eu" dos Princípios de psicologia (James, 1890, cap. 10). A apresentação da formulação jamesiana é feita no contexto do que o autor considera o objeto fundamental da psicologia, o fluxo de pensamento, uma conceituação que não requer nenhuma entidade interior como causadora ou originadora dos eventos psíquicos e atividades públicas do indivíduo. É verdade que nossa pesquisa procurava um conceito de eu que fosse assim caracterizado, isto é, como um criador interno, justamente para contrastar com o tratamento dado à questão pela análise do comportamento. Mas a maneira como James versou sobre esse objeto foi suficiente para alterar nossa intenção inicial. Deste modo, substituímos a ideia de contraste ou oposição por comparação ou afinidade. Certamente não encontramos apenas semelhanças, mas também divergências importantes; entretanto, em nossa opinião, todas se mostraram relevantes para a investigação do conceito de eu na psicologia em geral e naquela derivada da filosofia do behaviorismo radical. Nos parágrafos seguintes, resumiremos nosso procedimento para compor esta dissertação e expor as relações que identificamos e as nossas posições a respeito.

Em primeiro lugar, apresentamos uma síntese dos conceitos de eu que podem ser identificados na obra dos dois psicólogos considerados. No caso de James, a fonte para essa exposição foi o capítulo dos Princípios a que já nos referimos. É preciso dizer logo que não reproduzimos todos os detalhes que James retratou em seu texto. A pretensão de ecoar o estilo e a riqueza analítica do autor seria quixotesca. Mas, principalmente, escolhemos restringir nossa exposição do conceito jamesiano de eu por motivos de pertinência ao estudo comparativo que realizamos. Por exemplo, deixamos de lado seus comentários sobre o amor próprio e sua investigação das mutações do eu - por mais instigantes que sejam seus relatos de entrevistas com pacientes que tinham o que se costuma denominar distúrbios de personalidade. Concentramos nossa apresentação nos elementos que julgamos mais relevantes para 
a comparação com as ideias skinnerianas e para as dimensões de uma pesquisa de mestrado.

A parte da dissertação dedicada ao conceito de eu em Skinner não tem uma fonte única, como no caso de James. Julgamos que o célebre capítulo “O eu” (Skinner, 1953, cap. 18) era insuficiente para compor um quadro que abrangesse todos os elementos discutidos por James em sua exposição. Por isso, lançamos mão também de outros textos que compõem, juntamente com o capítulo mencionado, a seção "O indivíduo como um todo" de Ciência e comportamento humano (Skinner, 1953), assim como do capítulo "Pensamento" de Comportamento verbal (Skinner, 1957, cap. 19), além de usar como textos ancilares outros trabalhos do behaviorista.

Depois de apresentarmos as teorias de James e Skinner sobre o eu, redigimos uma tradução das ideias do primeiro em referências a contingências de reforço. Essa tradução foi feita no espírito do que o próprio Skinner sugeriu e realizou em diferentes ocasiões, e que justificamos no capítulo correspondente. Em nossa opinião, o fato mesmo de que as ciências progridem, no sentido apontado por Kuhn (1970), autoriza essa tradução. Sobretudo, construímos os argumentos desse capítulo a fim de evidenciar as afinidades entre as concepções dos dois psicólogos sobre o eu, por mais distintas que fossem, e para sugerir elementos para a imaginação experimental na pesquisa em laboratório dos fenômenos psicológicos diretamente relacionados com a subjetividade. Essa tradução, enfim, representa a primeira parte de nossa comparação entre os conceitos de eu em James e Skinner.

A segunda parte dessa comparação foi proposta no capítulo seguinte da dissertação, em que insinuamos influências de James sobre Skinner. Ali, a partir de similaridades e discordâncias que localizamos entre os dois pensadores a respeito do eu e de questões da psicologia em geral, debatemos algumas relações entre suas obras que nos pareceram importantes para descrever uma certa atitude científica e filosófica singular e produtiva para os pesquisadores da área.

No capítulo conclusivo da dissertação, estendemos nossos argumentos sobre as relações entre os pensamentos de James e Skinner, mencionamos os progressos que podemos obter a partir da teoria jamesiana na pesquisa em psicologia, sugerimos possíveis razões por que o programa delineado por ambos psicólogos é alvo do que 
parece ser uma posição reacionária, e propomos questões que julgamos interessantes para pesquisas posteriores.

James não fez parte dos autores estudados durante nossa graduação em psicologia; no máximo, seu nome foi rara e vagamente citado como um elemento da história da psicologia ou em referência à sua teoria das emoções. Tão surpreendente quanto conhecer melhor suas ideias durante o mestrado foi a dificuldade de encontrar estudos de outros autores sobre as relações entre James e Skinner.

Na história da psicologia de Figueiredo (1991), sua ligação é tênue e não aprofundada, e ainda parece não corresponder bem às tradições filosóficas que ambos fundaram, como afirmamos em certo ponto desta dissertação. Em outra obra (Figueiredo, 1992), dedicada à história da subjetividade, o mesmo autor excluiu qualquer consideração do conceito de eu jamesiano nos desenvolvimentos da psicologia moderna.

Em Abib (1996), James é revalorizado no contexto histórico da psicologia, mas não se exploram possíveis relações de influência entre ele e a análise do comportamento. Por outro lado, um seu artigo posterior (Abib, 1999) expõe um conceito jamesiano de eu, entendido como subjetividade, a partir do mesmo capítulo dos Princípios que usamos nesta dissertação como fonte principal; ali, entretanto, a ênfase está na descrição das ideias de James e não em maneiras de interpretá-las conforme outras teorias, como a que fundamenta por exemplo a análise do comportamento.

Baum (2006) menciona James em diferentes ocasiões como uma das principais referências do pragmatismo e a similaridade entre essa filosofia e a atitude científica da análise do comportamento skinneriana, mas não discute o empirismo jamesiano ou os Princípios de psicologia e suas possíveis relações com o behaviorismo radical.

A abrangente tese de Tourinho (2006) que versou sobre a subjetividade do ponto de vista da análise do comportamento não incluiu considerações sobre o conceito de eu de James.

O trabalho que encontramos, já perto de concluir esta dissertação, que se mostrou mais próximo de nossas intenções de pesquisa, é o de Malone (1975), em que o autor destaca similaridades entre os programas de James e Skinner para a 
psicologia. Em alguns pontos, nossa interpretação das teorias convergiu com a apresentada nesse artigo, mas na maior parte realizamos um percurso distinto, à medida que os argumentos de Malone procuram criticar o que ele considerou vago e excessivo quanto ao conceito de reforço na teoria skinneriana, que deveria de certa maneira ser aperfeiçoada a partir do que James descreveu em seus Princípios.

Entregamos assim os argumentos desta dissertação aos leitores, e esperamos, com James (1912b), que contribuam na psicologia como um "possível fermento de novos desenvolvimentos".

\subsection{Sobre as citações}

Ao longo de toda a dissertação, reproduzimos vários excertos de obras de William James. Decidimos fazer isso não só por causa da beleza do estilo do autor, por mais que essa fosse uma boa razão em si. Como afirmou Malone (1975, p. 144), quem não leu James "perdeu a mais clara prosa e a mais esclarecida autodescrição jamais escrita". Citamos James várias vezes também para compartilhar com os leitores a oportunidade de entrar em contato com um autor que, embora seja muito conhecido, é pouco lido.

Em muitos lugares, lançamos mão de citações de obras literárias como exemplos de experiências subjetivas, como se utilizássemos relatos de pessoas de carne e osso. Ao fazer isso, seguimos uma ideia de Skinner (1957, p. 98):

O comportamento humano é um assunto extremamente difícil. Os métodos da ciência vieram a ser aplicados a ele muito tarde na história da ciência, e suas considerações ainda estão longe de ser completas. Mas é o campo em que a literatura é a mais competente, segura e eficaz.... o escritor muitas vezes parece "dizer algo" sobre o comportamento humano, interpretá-lo e analisá-lo. Uma pessoa não é descrita como fazendo parte de episódios variados, ela é caracterizada.

Finalmente, gostaríamos de registrar que somos o tradutor de todas as citações cujas fontes estão em língua estrangeira. 


\section{2}

\section{CONCEITO DE EU SEGUNDO JAMES}

Apresentaremos neste capítulo uma descrição do conceito jamesiano de eu a partir do exposto no capítulo "A consciência do eu" (James, 1890, cap. 10). É importante ressaltar que o eu não é, nos Princípios de psicologia, o objeto fundamental da pesquisa em psicologia; é um dentre os seus temas, assim como a atenção, o hábito, a memória, o instinto, a vontade etc.

Psicologia é a ciência da vida mental, tanto de seus fenômenos quanto de suas condições. Os fenômenos são coisas tais como o que chamamos sentimentos, desejos, cognições, razões, decisões e afins; e, superficialmente consideradas, sua variedade e complexidade são tais que deixam uma impressão caótica no observador (James, 1890, p. 1).

O conceito de eu em James divide-se em eu empírico e ego puro. O primeiro é descrito em três aspectos: seus constituintes (material, social, espiritual), os sentimentos e emoções por ele suscitados, e as ações por ele incitadas. O segundo é o princípio de identidade pessoal teoricamente considerado, a que James dedicou uma análise mais filosófica que científica, mas a fim de deixar claro o seu ponto de vista sobre como a psicologia pode tratar da questão num plano empírico ao invés de metafísico.

\subsection{Eu material}

O eu material corresponde às condições tangíveis que servem de "suporte", por assim dizer, à realidade física do indivíduo. Sua base fundamental é o corpo, sua condição de organismo, de ente biológico: um corpo que tem duração finita, que ao mesmo tempo mantém uma identidade e transforma-se, desde o desenvolvimento embrionário até os últimos momentos de vida. Em outras palavras, o corpo é sempre o mesmo e sempre diferente, à medida que muda conforme determina a interação 
entre as predisposições internas, genéticas, e as condições ambientais que formam o espaço em que o organismo vive.

O corpo também é, por assim dizer, a origem das necessidades de subsistência do eu. A condição de ser um organismo vivo impõe ao indivíduo alimentar-se, beber, repousar, reproduzir-se, enfim, o conjunto de atividades cuja finalidade é sustentar a continuidade de sua vida. Igualmente, é essa condição que obriga o eu material a conservar-se, a proteger sua integridade de condições nocivas, ambientais ou impostas por outros organismos.

Além do corpo, James enumera como elementos pertencentes à materialidade do eu: as roupas, os parentes próximos, a casa e os bens e objetos pessoais. O indivíduo apropria-se de suas roupas num sentido íntimo, como parte de quem ele é; o indivíduo identifica-se com elas. Pai e mãe, cônjuge e filhos, todos são parte do eu; suas alegrias e dores afetam o eu, e a morte de qualquer deles significa uma parte do eu que se perde. A casa não é um espaço físico apenas; as cenas domésticas fazem parte da vida, inumeráveis sentimentos são despertados pelos ambientes da casa, assim como memórias que dão identidade ao indivíduo. Igualmente, elogios e críticas de um visitante são tomados como cumprimentos e ofensas pessoais. Nas palavras de James (1890, p. 189): “Todos nós temos um impulso cego de resguardar nosso corpo, cobri-lo com roupas de maneira ornamental, acalentar pais, esposa e filhos, e encontrar para nós um lar próprio em que possamos morar e 'ser melhores' ".

O último elemento do eu material são tanto riquezas quanto objetos, valiosos ou não, mas que têm valor afetivo. Reunir bens e coisas acrescenta ao eu partes de sua identidade; o indivíduo se compraz não só pelo valor econômico das coisas que possui mas especialmente pela dimensão de valorização subjetiva que experimenta.

\subsection{Eu social}

Conforme James (1890, p. 189), esse constituinte pode ser sintetizado pela fórmula: o eu social de um indivíduo é o reconhecimento que ele obtém de seus pares. 
O ser humano não apenas vive em sociedade; a própria identidade de cada sujeito depende da aprovação e das críticas a ele dirigidas pelos outros. Ser ignorado por pessoas que se reconhece como importantes, por exemplo, reduz o indivíduo à condição de coisa.

Uma consequência relevante dessa formulação é a de que existem diferentes eus sociais num mesmo indivíduo. Uma pessoa é diferente em meio à própria família do que quando está entre os amigos da escola ou do trabalho, por exemplo. James afirma que cada pessoa com quem o indivíduo se relaciona carrega uma imagem dele na mente, e essa imagem determina parte da identidade do indivíduo, cada um de seus eus sociais. Discutiremos essa "imagem" mais adiante, no capítulo sobre a tradução das ideias de James em termos pesquisáveis pela análise do comportamento.

Há, assim, tantos eus sociais quantos há grupos distintos com cuja opinião se importa o indivíduo. Em particular, o mais específico eu social de alguém reside na mente da pessoa que ele ou ela ama. Os afetos suscitados pela pessoa amada são os que mais intensamente conferem ou abalam identidade social ao indivíduo. Daí os efeitos avassaladores sobre um indivíduo diante de sinais ambivalentes da pessoa que ele ama.

Os eus sociais também podem ser descritos por palavras como fama, honra e desonra. São determinantes de decisões e atitudes do indivíduo em relação aos grupos que sustentam sua fama ou estabelecem sua honra ou desonra. Assim, por exemplo, “o ladrão deve não roubar de outros ladrões; o apostador deve pagar suas dívidas de jogo, embora não pague nenhuma outra dívida no mundo" (James, 1890, p. 190-191). Do mesmo modo, "você deve aceitar o desafio de um igual, mas se é desafiado por um inferior você pode rir dele e desprezá-lo" (James, 1890, p. 191).

\subsection{Eu espiritual}

Por chamar-se espiritual o terceiro constituinte do eu não se deve entretanto compreendê-lo como um elemento não empírico. $\mathrm{O}$ eu espiritual deve ser considerado concretamente, como o ente interior, subjetivo, em que o indivíduo se 
reconhece, assim como reconhece suas faculdades ou disposições psíquicas. James (1890, p. 191) afirma:

Essas disposições psíquicas são a parte do eu mais duradoura e íntima, a parte que nós mais verdadeiramente parecemos ser. Obtemos uma autossatisfação mais pura quando pensamos em nossa habilidade de argumentar e discriminar, em nossa sensibilidade e consciência morais, em nossa vontade indomável, do que quando examinamos quaisquer de nossas outras posses. Somente quando aquelas [disposições psíquicas] estão alteradas declara-se que um homem está alienatus a se.

Um indivíduo está fora de si ("alienatus a se”), ou alienado mentalmente, quando não pode ou não consegue reconhecer essas disposições como parte de sua identidade. O eu espiritual recobre-se, deste modo, de um caráter reflexivo. Isto é, ele exige deixar de lado o ponto de vista externo, centrado por exemplo nas imagens mentais dos outros, para pensar sobre a própria condição subjetiva, para que o indivíduo se reconheça como um pensador separado dos outros.

Ainda mais especificamente, James argumenta que o eu espiritual depende de que o sujeito discrimine o pensamento em si do objeto sobre o que o pensamento opera. A respeito desta diferença sutil, ou difícil de delimitar, James (1890, p. 191192) argumenta:

As bases mais profundas dessa discriminação talvez possam ser difíceis de encontrar; mas bases superficiais são abundantes e estão à mão. Quase todos nos dirão que o pensamento tem um diferente tipo de existência em comparação com as coisas, porque muitos tipos de pensamento não são sobre coisas - por exemplo, prazeres, dores e emoções -; outros são sobre coisas inexistentes - erros e ficções -; outros ainda de coisas existentes, mas de uma forma que é simbólica e não se assemelha a elas - ideias e conceitos abstratos -; enquanto nos pensamentos que se assemelham mesmo às coisas "de" que eles são (perceptos, sensações), podemos sentir, paralelamente à coisa conhecida, o pensamento dela decorrendo na mente como um ato e operação inteiramente separados. 
O eu espiritual é sentido, isto é, o indivíduo reconhece a si mesmo no espaço "adimensional" de sua intimidade. Continuamos a caminhar sobre um campo de distinções sutis mas importantes. James afirma que o eu espiritual não é o ente racional que filosofias tradicionais consideram ser a identidade do sujeito que pensa, quer dizer, ele não é uma cognição, um agente intelectual; não é a soma de memórias que constroem uma história individual; não é uma palavra apenas, como os pronomes "eu" e "mim", a denotar um ser imaginário ou a fazer parte de estruturas sintáticas. O indivíduo sente o eu espiritual. Sobre esta ideia, James (1890, p. 193) diz que o eu espiritual é sentido "assim como o corpo é sentido, e o sentimento do corpo é também uma abstração, porque nunca se sente o corpo sozinho, mas sempre junto com outras coisas". Daí o paralelismo mencionado no parágrafo anterior, entre o pensamento "de" algo e aquele sobre o reconhecimento de pensar "em si" e "por si".

Vale reiterar, finalmente, que a qualificação "espiritual", no que diz respeito a determinar em termos introspectivos o que sente o indivíduo quando reconhece seu eu espiritual, não significa que esse objeto está fora do alcance dos métodos de pesquisa das ciências naturais. Rigorosamente, o eu espiritual poderia ser compreendido em termos de processos puramente corporais (James, 1890, p. 193). Em outras palavras, se o eu espiritual é o que faz diferença na forma de um intermediário personalizado entre conteúdos psíquicos (ideias, perceptos, sensações, vontades etc.) e comportamentos públicos (ações exercidas sobre o ambiente e outros organismos), ele seria uma coleção de atividades não diferentes fisiologicamente dos próprios atos públicos. O eu chamado espiritual pode ser traduzido em termos operacionais, relacionados a atividades do sistema nervoso teórica ou praticamente observáveis. Voltaremos a esta questão mais adiante, quando discutirmos o problema do ego puro em James e Skinner.

\subsection{Ego puro}

No capítulo "A consciência do eu" dos Princípios de psicologia, James usou mais que o dobro de páginas para discutir o ego puro do que para investigar os outros aspectos do eu. A longa análise feita pelo autor apresenta um abrangente apanhado 
de teorias filosóficas sobre o que seja o eu e é um grande exercício crítico em busca de relacioná-las (ou abandoná-las) em face das condições de pesquisa possíveis em psicologia, entendida como uma ciência natural. Entretanto, optaremos nesta dissertação por não reproduzir em detalhes o estudo do ego puro proposto por James; para as finalidades deste mestrado, bastarão alguns elementos resumidos, escolhidos a partir dos argumentos do autor.

O ego puro é o princípio de identidade pessoal que o indivíduo reconhece em si mesmo em todas as diferentes formas de seus "eus" (material, social, espiritual). Nas palavras de James (1890, p. 213), trata-se do "mais enigmático quebra-cabeça com que a psicologia tem de lidar". De fato, para lidar com isso em sua psicologia, o autor lança mão da filosofia, agrupando diferentes ideias sobre o ego em três grupos de teorias: a espiritualista, a associacionista e a transcendentalista.

A teoria espiritualista também pode ser chamada de teoria da alma. James afirma que suas raízes estão na filosofia popular e na escolástica, que, aliás, não seria mais do que a filosofia popular sistematizada (James, 1890, p. 221). Seu raciocínio básico é o seguinte. Posto que os fenômenos psíquicos são atividades, e que não existem atividades sem que haja um agente concreto, o princípio interior de identidade de um sujeito, seu ego puro, deve ser substancial. Além disso, esse agente substancial não pode ser o cérebro, que é composto de matéria; a atividade do cérebro é o pensamento, que tanto é imaterial quanto pode conhecer coisas imateriais. Mas a matéria é incompatível com os poderes requeridos para executar essas funções. Ainda, o pensamento é espontâneo, livre, algo também incompatível com a matéria, que é determinada externamente. Portanto, o agente substancial deve ser outra coisa, algo como o que se denomina alma. Um resumo das críticas do autor a essa teoria pode ser identificado na seguinte declaração: “No todo, a Alma é uma progênie daquela maneira de filosofar cuja grande máxima é, de acordo com o Dr. [Richard] Hodgson: 'O que quer que você seja totalmente ignorante a respeito, declare ser a explicação de todo o resto' "' (James, 1890, p. 223).

William James menciona como principais originadores da teoria associacionista os filósofos John Locke e David Hume, ainda que mencione vários outros autores. De acordo com o que James interpreta a partir das obras desses 
pensadores, e em termos bastante resumidos a partir de nossa leitura, a mente seria constituída pela associação, numa unidade, de uma diversidade de ideias distintas entre si. As ideias sucedem-se umas às outras, e ao mesmo tempo cada uma é separada das outras. Deste modo, a ideia de $X$ mais a ideia de $Y$ seria diferente da ideia de $\mathrm{X}$ mais $\mathrm{Y}$. Em outros termos, no que diz respeito à ideia de ego, ou melhor, à ideia de uma identidade pessoal, sua importância residiria em sua unidade verificável e sentida, ainda que transitória, à medida que se constituiria como uma consciência da diversidade. Na teoria associacionista do ego, uma "unidade metafísica ou absoluta seria insignificante" (James, 1890, p. 226). Entretanto, afirma James (1890, p. 228) sobre os associacionistas: “embora eles sejam bastante explícitos sobre o que [o ego puro] é, quer dizer, uma sucessão de sentimentos e pensamentos, eles são muito tímidos quanto a declaradamente tratar do problema de como ele vem a ser consciente de si mesmo". Deste modo, o que observa, reconhece ou percebe como a identidade pessoal do sujeito deve ser postulado como algo além da corrente de ideias associadas.

A terceira teoria que James cita sobre o ego puro é a transcendentalista, cuja origem ele atribui a Immanuel Kant. Em termos bastante simplificados, a consciência de que "eu penso" estaria implícita em toda experiência de conhecimento; para todo objeto conhecido, a condição necessária é a de que haja um sujeito que conhece. Esse ego, segundo James (1890, p. 233), é chamado por Kant de “Unidade de Apercepção original sintética transcendental". Ainda segundo James, o ego transcendental, embora se assemelhe à alma da teoria espiritualista, é entretanto desprovido de características positivas; ele seria a simples e integralmente vazia ideia de eu. Mas, se considerarmos, como James (1890, p. 235), que esse ego é um agente, então o "transcendentalismo é apenas o substancialismo que ficou envergonhado, e o ego apenas uma edição 'reles e barata' da alma".

Para concluir esta seção, cremos que James apresenta os três grupos de teorias sob a exigência de discutir do ponto de vista metafísico o princípio de identidade pessoal por ele denominado ego puro. Nenhuma das teorias, entretanto, resulta na definição de objetos empiricamente pesquisáveis, uma forte razão para que James 
não as incorpore. O ego puro, como um constituinte do eu, não é uma ideia, não é uma alma, não está fora do tempo.

É um Pensamento, a cada momento diferente do momento anterior, mas apropriador do último, juntamente com tudo que o anterior chamava de seu. Todos os fatos experienciais encontram seu lugar nessa descrição, sem o ônus de nenhuma hipótese salvo aquela da existência de pensamentos ou estados mentais passageiros. O mesmo cérebro pode servir a muitos eus conscientes, sejam alternados, sejam coexistentes; mas através de quais modificações em sua ação, ou se condições transcerebrais podem intervir, são questões que não podem ser agora respondidas (James, 1890, p. 259).

\subsection{Sentimentos e emoções suscitados pelo eu}

Os constituintes do eu, descritos na seção anterior, têm correspondentes em sensações, perceptos e emoções que podem ser reunidos sob o termo cenestesia. Geralmente, o conceito refere-se às sensações que o indivíduo tem a respeito de sua própria condição (estados corporais, por exemplo, assim como o relato verbal de seus sentimentos para si mesmo) e a respeito de sua própria identidade. Para James, porém, nos Princípios de psicologia, onde se usa a expressão self-feeling para designá-la em inglês, a cenestesia reúne a autocomplacência e a autoinsatisfação.

Autocomplacência e autoinsatisfação são conjuntos conflitantes de sentimentos e emoções. Ambas têm no vernáculo uma grande variedade de termos que identificam seus elementos. Assim, a primeira reuniria, por exemplo, orgulho, presunção, vaidade, autoestima, arrogância, vanglória. A segunda conteria modéstia, humildade, desorientação, insegurança, vergonha, mortificação, contrição, repúdio de si mesmo, desespero.

\subsection{Ações incitadas pelo eu}

James (1890, p. 198) afirma que as ações incitadas pelo eu decorrem de "nossos impulsos instintivos fundamentais". Essas ações, como os elementos da cenestesia, 
também são agrupadas em dois conjuntos: de autopreservação e de autofavorecimento (no original, respectivamente self-preservation e self-seeking). A diferença básica é que a primeira trata de manter uma condição presente do eu, e o segundo cuida obter bens ou vantagens futuros para o eu.

Talvez a autopreservação possa ser mais facilmente identificada com “impulsos instintivos”. Nas palavras de James (1890, p. 198): “Todos os movimentos e ações reflexos, comuns e úteis de alimentação e defesa são atos de autopreservação corporal. Medo e raiva incitam atos que são úteis da mesma maneira". Entretanto, é algo difícil distinguir os dois conjuntos de ações incitadas pelo eu à medida que consideramos as várias ações de autofavorecimento relacionadas pelo autor às finalidades de obter benefícios para o eu material: caçar para obter alimentos, adquirir coisas, construir abrigos e ferramentas, e também amabilidade, afeto aos pais, curiosidade e emulação. Vale destacar que em James, portanto, os "impulsos instintivos" revestem-se de características que tenderiam a ser parte da explicação por que os seres humanos produzem a cultura e são por ela condicionados.

O autofavorecimento desdobra-se também de maneira correspondente frente aos eus social e espiritual. Aquele social reúne, deste modo, as ações cujo objetivo é o reconhecimento do indivíduo por parte de seus semelhantes. Neste caso, todas as ações incitadas pelo eu social são executadas desde que sejam úteis para alcançar reconhecimento e aprovação social. Por exemplo, nas palavras de James (1890, p. 199):

É claro que amigos distintos e reconhecimento admirado são os mais desejáveis Thackeray, em algum lugar, pede para seus leitores confessarem se não daria a cada um deles um prazer sublime ser visto caminhar com um duque em cada braço ao longo da Pall Mall [rua londrina com muitos clubes chiques]. Mas na falta de duques e saudações invejosas quase qualquer coisa servirá para alguns de nós; hoje há toda uma raça de seres cuja paixão é manter seus nomes nos jornais, não importa sob qual título, "chegadas e partidas", "textos a pedido", "entrevistas" - fofocas, e mesmo escândalos, convirão a eles se não houver nada melhor. 
Quanto à forma espiritual do autofavorecimento, trata-se das ações que procuram obter progresso intelectual ou moral, por exemplo. Entretanto, James (1890, p. 199) pondera que as ações especificamente espirituais seriam "apenas autofavorecimento material e social além-túmulo. No desejo muçulmano pelo paraíso e na aspiração cristã de não ser condenado ao inferno, a materialidade dos bens almejados é indisfarçada".

\subsection{Adendo}

Concluímos por ora as considerações sobre o eu nos Princípios de psicologia. Entretanto, ainda há um item importante para as comparações entre James e Skinner, que deixaremos para tratar quando comentarmos as afinidades e divergências entre as teorias dos dois psicólogos: a rivalidade e o conflito dos diferentes eus (uma questão relacionada com os constituintes do eu). 


\section{CONCEITO DE EU SEGUNDO SKINNER}

Tanto na análise do comportamento quanto na filosofia do behaviorismo radical, ao falar do eu caminhamos sobre um terreno em que se debatem concepções tradicionais, oriundas do senso comum ou do vocabulário leigo, e formulações científicas, baseadas seja em termos de relações entre comportamento e contingências de reforço, seja em termos de relações entre atividades cognitivas ou intencionais do indivíduo e o funcionamento do cérebro. Esse debate não é necessariamente esclarecedor; muitas vezes é enganoso. Um exemplo, dentre vários possíveis, pode ser encontrado num artigo recente sobre um possível conceito transespecífico de eu: a "neurociência pode agora perseguir... a ideia de que todos os mamíferos compartilham substratos cerebrais fundadores de um núcleo de eu que lhes permite serem criaturas ativas no mundo em oposição a simplesmente serem receptores passivos de informação" (Northoff \& Panksepp, 2008, p. 259). Terem os autores usado a palavra "criaturas" para se referirem a organismos individuais talvez sugira algo sobre o que pensam a respeito da origem das espécies, mas pode ter sido apenas um uso coloquial do termo para designar os animais. O que esse uso certamente revela é a ideia tradicional de que o eu origina, determina, inicia comportamentos (ou, pelo menos, aqueles que se podem traduzir operacionalmente como indicadores de subjetividade).

Ao fazer esse comentário crítico à ideia de um eu criador, não procuramos repetir a busca do filósofo cínico Diógenes por um homem honesto, com uma lanterna na mão em plena luz do dia nas ruas de Atenas. A questão é que quando não se identificam as condições que explicam as atividades de um indivíduo é comum atribuir a origem de seu comportamento a um agente em seu interior, ainda que esse agente seja o cérebro, investido de características que nos levariam de volta à análise de James (1890, p. 221-226) sobre a teoria da alma, que sintetizamos no capítulo anterior.

À primeira vista, qualquer consideração sobre o eu seria supérflua no behaviorismo radical. Afinal, a ciência derivada dessa filosofia investiga o 
comportamento e suas relações com eventos físicos, e é o organismo quem se comporta, tem uma história filo e ontogenética e vive num certo ambiente que se transforma ou se repete ao longo do tempo; deste modo, não é preciso supor que exista um eu que inicia ou dirige o comportamento.

Porém, a complexidade das ações humanas e a enorme variedade das particularidades das existências individuais dos seres humanos, implícitas na descrição que fizemos sobre o eu em James, exigem uma investigação mais detalhada por parte da análise do comportamento, em vez da simples eliminação do eu do campo de pesquisa. "Podemos objetar a qualquer análise que apela para um eu ou uma personalidade como um determinante interior da ação, mas os fatos que têm sido representados por esses dispositivos não podem ser ignorados" (Skinner, 1953, p. 284).

O que poderíamos definir como uma teoria do eu em análise do comportamento? Apresentaremos nas próximas seções o que podemos identificar como os principais elementos que permitem à análise do comportamento investigar o eu, seu significado e sua possível condição de objeto em psicologia. A fonte para nossa exposição é a seção “O indivíduo como um todo", da obra Ciência e comportamento humano (Skinner, 1953) e o capítulo "Pensamento" do livro Comportamento verbal (Skinner, 1957, cap. 19). Para abordar especificamente a teoria de Skinner sobre o eu, é preciso antes passar por dois importantes itens de pesquisa: o autocontrole do comportamento e o pensamento.

\subsection{Autocontrole}

Uma importante consequência da análise do comportamento é a ideia de controle (Skinner, 1953, p. 227); quando estabelecemos uma relação funcional entre uma variável independente e uma dependente, podemos manipular a primeira para obter resultados determinados na segunda.

A concepção de explicação científica em análise do comportamento implica poder interpretar, prever e controlar o objeto de estudo (Skinner, 1953, p. 12-14). Explicações como essas, no entanto, não são exclusivas do cientista. Na vida 
cotidiana, o assim chamado leigo ou indivíduo comum realiza atividades semelhantes àquelas. Controlamos nosso comportamento, por exemplo, ao anotar e ler nossas tarefas numa agenda, ao tomar café para obter uma certa disposição para emitir respostas com mais rapidez e precisão, ao encaixotar ou descartar retratos de um amor não correspondido, ao entregar as chaves do carro a um amigo sóbrio quando bebemos num bar.

Em certo sentido, podemos chamar isso tudo de autodeterminação da conduta. $\mathrm{O}$ indivíduo controla condições que determinam outros comportamentos seus de maneira análoga a como controla o comportamento de outras pessoas.

Mas, quando um indivíduo controla o próprio comportamento, quem controla quem? Afinal, ele é um organismo só, não é uma multiplicidade de organismos. Entretanto, "evidentemente os eus são múltiplos e assim não devem ser identificados com o organismo biológico" (Skinner, 1953, p. 229), embora essa identificação seja proposta ainda hoje (por exemplo, Northoff \& Panksepp, 2008). Mais adiante, trataremos das dimensões do eu e sua multiplicidade, assim como de outras questões relacionadas. Por ora, vamos nos concentrar nas condições em que ocorre o autocontrole, e suas formas ou técnicas.

O autocontrole usualmente ocorre quando há conflito de contingências de reforço. Uma resposta pode ter por consequência, por exemplo, reforçadores positivos imediatos e punidores postergados. Beber álcool, fumar e comer fast food são exemplos típicos. No caso do consumo de tabaco, há uma boa exposição desse conflito em Baum (2006, p. 194-197). Para especificar melhor um desses exemplos: os pratos de fast food geralmente contêm enormes quantidades de gordura, sal, condimentos e açúcares, e estão disponíveis rapidamente para o consumo. Tanto seus ingredientes quanto a velocidade com que ficam prontos tornam-nos poderosos reforçadores imediatos para o comportamento de ingeri-los. A longo prazo, entretanto, seu consumo reiterado leva a consequências punitivas para o indivíduo, como problemas cardíacos e obesidade. O conflito ocorre não só por serem as consequências reforçadoras e punitivas, mas também porque umas e outras dão-se em momentos significativamente separados no decorrer do tempo. No caso de beber álcool, a ressaca do dia seguinte é um punidor não muito distante dos reforçadores 
obtidos com o comportamento do indivíduo na festa da véspera, e assim pode submetê-lo ao conflito entre as consequências de beber. Mas na alimentação descuidada esse conflito pode mostrar-se "tarde demais" ou, em outras palavras, quando já houve um acúmulo de males causados pela comida pouco nutritiva. De qualquer maneira, quando o sujeito se depara com a oportunidade de repetir a dieta de fast food, podem-se gerar estímulos aversivos condicionados (decorrentes da história de condicionamento determinada pelas consequências punitivas anteriores) e, com eles, um estado emocional como culpa ou vergonha, incompatível com as respostas emocionais que normalmente acompanham a obtenção de consequências reforçadoras positivas para um comportamento. Em situações como essa, qualquer comportamento que diminua a probabilidade de emissão da resposta punida (comer fast food, digamos) será reforçado negativamente porque suprime a estimulação aversiva condicionada; esse comportamento faz parte do tipo de atividades agrupadas sob a denominação de autocontrole.

Temos, deste modo, um quadro em que uma resposta é emitida para que a probabilidade de outra seja alterada. A primeira denomina-se resposta controladora; a segunda, resposta controlada. Mas a maneira como a resposta controladora muda a força da controlada pode ocorrer em condições bastante distintas. Por isso, vamos percorrer brevemente os diferentes modos como o autocontrole pode ser exercido.

O indivíduo muitas vezes controla seu comportamento por meio de restrição ou de ajuda física, quer dizer, submetendo o próprio corpo a limitações incompatíveis com a emissão das respostas controladas ou a condições que facilitam a sua emissão. Uma amostra banal seria a de apertar as narinas com a mão ao mergulhar, o que permite ao indivíduo esquivar-se das consequências aversivas de respirar sob a água ou, por outro lado, o uso de equipamento de mergulho para que sua respiração possa ocorrer mesmo naquele ambiente incomum. Tapar a boca com a mão para abafar o ruído de tossir ou para evitar dizer algo inapropriado também são exemplos, neste caso mantidos porque a pessoa esquiva os punidores sociais que se seguiriam a tossir durante um concerto ou a ofender alguém importante. Trocar um computador antigo, que funciona mal, por um novo e mais rápido pode ser uma maneira de controlar o próprio comportamento, no sentido de facilitá-lo. Respostas emocionais 
também podem ser controladas por meio de uma certa forma de restrição física: quando uma pessoa se afasta de um lugar em que está sentindo raiva a fim de se acalmar, ela evita tanto o estado emocional continuado quanto as consequências sociais punitivas de agredir outros indivíduos e objetos. Dentre os vários exemplos imagináveis, o suicídio configura-se como um caso extremo de restrição física, ainda que a essa forma de comportamento seja absurdo considerar a noção de frequência de resposta. Um indivíduo pode matar-se para proteger outras pessoas (quem sabe, para não revelar segredos sob tortura) ou evitar uma desonra "pior que a morte" (como no haraquiri). Igualmente, o suicídio pode ser uma forma extrema de suprimir um sofrimento causado por condições sociais terríveis: "num universo subitamente privado de luzes ou ilusões, o homem se sente um estrangeiro. Esse exílio não tem saída, pois é destituído das lembranças de uma pátria distante ou da esperança de uma terra prometida" (Camus, 1942, p. 26).

Alterar a probabilidade das respostas controladas através da mudança de estímulos está mais diretamente ligado a processos comportamentais. No controle por restrição ou ajuda, as respostas controladoras tornavam quase impossíveis as respostas controladas ou produziam condições em que essas podiam enfim ocorrer. Quando um indivíduo muda os estímulos, por sua vez, ele cria ou elimina as ocasiões para que o comportamento ocorra ou não. A diferença básica está no objeto da resposta controladora: na restrição ou ajuda física, ela atua sobre o corpo; mudar os estímulos significa agir no ambiente. O indivíduo manipula estímulos que eliciam respondentes ou evocam operantes. Quando uma pessoa vê o clarão de um raio e rapidamente tapa os ouvidos com os dedos, diminui a intensidade da resposta incondicionada que será eliciada pelo som do trovão que se seguirá. Quando desliga o rádio, suprime estímulos que evocariam respostas incompatíveis com o comportamento de ler ou escrever, por exemplo. Naturalmente, a manipulação de estímulos não é reforçada somente negativamente. Aperitivos eliciam respostas que propiciam ingerir e degustar os alimentos da refeição principal, e bons livros evocam redigir textos claros e significativos.

Falamos de maneira um pouco detalhada sobre duas formas de autocontrole: restringir ou propiciar a emissão das respostas controladas através de ações sobre o 
próprio corpo, e suprimir ou produzir estímulos que controlam a probabilidade das respostas controladas. Cremos que essas duas formas são prototípicas, e por isso falaremos de maneira mais breve sobre outras condições que, manipuladas pelas respostas controladoras, levam à alteração da probabilidade das respostas controladas.

Agindo sobre a privação e a saciação, um indivíduo muda a frequência e a duração da resposta controlada. A eficácia de uma das sugestões básicas de redução de danos no consumo de álcool, a de beber água entre um drinque e outro, pode ser compreendida em termos dos efeitos da saciação. Um exemplo oposto seria, durante uma refeição, o de "guardar espaço" para a sobremesa. Vale ressaltar que manipular a privação e a saciação pode ser reforçado pelo controle obtido sobre operantes mantidos por reforçadores distintos dos manipulados; assim, observamos indivíduos que suprimem seu comportamento sexual através de exercícios físicos intensos, e vegetarianos tenderiam a ser mais alertas porque em certo sentido sempre estão com um pouco de fome.

Alterar emoções, preparar a apresentação de estímulos aversivos, estabelecer regras para ter acesso a reforçadores, usar drogas e emitir comportamentos incompatíveis são outras formas sob as quais o autocontrole pode ser identificado. Ouvir música romântica antes de encontrar o namorado ou namorada, armar um despertador para levantar-se cedo, permitir-se ir ao cinema somente depois de terminar um trabalho, tomar café para ficar alerta, "rir para não chorar" - são todas respostas controladoras corriqueiras que agem sobre a probabilidade das respostas controladas.

Discutimos até aqui o que é e como ocorre o autocontrole. Falta, portanto, falar sobre por que o autocontrole é mantido. Em outras palavras, é preciso investigar qual é em última instância a fonte que mantém a força das respostas controladoras emitidas pelo próprio indivíduo. Quando mencionamos o conflito entre reforçadores de curto e longo prazo, identificamos uma origem "natural" do autocontrole. Especificamente no caso dos seres humanos, as condições que mantêm o autocontrole são sobretudo arranjadas pela comunidade verbal e atuam ao longo da história de episódios sociais de que um indivíduo participa desde a infância. Moderar-se ao beber, ter uma certa aparência, respeitar diplomaticamente a 
sensibilidade alheia, trabalhar duro, seguir uma religião, respeitar as leis - toda a infinidade de atividades que compõem o cotidiano de um ser humano na vida em sociedade depende de reforçadores condicionados muito distintos daqueles disponíveis no ambiente natural. A seleção natural produziu filogeneticamente uma forma natural de "autocontrole" (como os efeitos da saciação, por exemplo) e a história de condicionamento ontogenética faz surgir um certo autocontrole à medida que o indivíduo experimentou o conflito de reforçadores de curto e longo prazo (como a ressaca conseguinte à embriaguez). Entre seres humanos, é preciso destacar que a história de condicionamento social é fundamental para modelar e sustentar o autocontrole do indivíduo (a tal ponto que é capaz de suprimir comportamento sexual antes mesmo de sua primeira emissão, como no controle exercido por agências religiosas sobre a virgindade feminina em diferentes culturas).

Antes de prosseguirmos, vale lembrar que a exposição sobre o autocontrole que agora concluímos será importante como um dos fundamentos do conceito de eu skinneriano, assim como para a tradução das ideias de James em contingências de reforço no próximo capítulo da dissertação.

\subsection{Pensamento}

Abordaremos a atividade de pensar a partir do que expusemos sobre as condições em que ocorre o autocontrole; neste caso, basearemos nossa investigação na análise do comportamento verbal. Para lembrar, as duas características fundamentais do comportamento verbal são: o reforço é mediado pela ação de um organismo, e as contingências são arranjadas por um comunidade verbal. O objetivo é apresentar, com Skinner (1957), a ideia de que pensamento é comportamento. Começaremos pela análise dos episódios verbais em que falante e ouvinte são o mesmo indivíduo.

Podemos cogitar situações em que o reforço das respostas verbais ocorre simplesmente porque o indivíduo "gosta de ouvir sua própria voz", quando elabora fantasias verbais para si. “A expressão: 'Conversar com os seus botões', parecendo simples metáfora, é frase de sentido real e direto. Os botões operam sincronicamente 
conosco; formam uma espécie de senado, cômodo e barato, que vota sempre as nossas moções" (Machado, 1891, cap. 142, p. 145). Mas a fonte crucial do reforço são as consequências práticas de falar consigo mesmo.

Nos episódios em que falante e ouvinte são o mesmo indivíduo, ocorre autoestimulação verbal, como no automando e no autotacto. Um automando - um mando dirigido a si mesmo - pode facilitar ou dificultar a emissão de outras respostas, verbais ou não. Ao despertar numa manhã fria, dizer a si mesmo “Levanta!", em primeiro lugar é mais fácil, quer dizer, tem consequências menos aversivas do que deixar a cama, e em segundo lugar induz o comportamento de levantar-se (o controle de estímulo decorre das ocasiões passadas em que o mando foi eficaz em induzir o comportamento em outras pessoas).

Autotactos - tactos dirigidos ao próprio indivíduo - também são reforçados por controlar outras respostas do mesmo sujeito. Assim como uma agenda pode ser o suporte de mandos que uma pessoa prepara para si, a fim de emitir certas respostas nos momentos apropriados, um diário pode servir para registrar tactos controlados por estímulos presentes, aos quais o indivíduo responderá, numa ocasião futura, como leitor. Mas autotactos podem ser importantes também no momento em que são emitidos; quando não há estimulação suficientemente eficaz para evocar uma resposta discriminada, verbal ou não, o autotacto pode aumentar o controle de estímulo à medida que, por exemplo, "dê nome aos bois".

Uma interessante consequência do autotacto provém de não estarem aí presentes as relações de controle do ambiente verbal externo. Em outras palavras, torna-se muito mais provável a emissão de tactos distorcidos. O indivíduo pode mentir para si mesmo, inventar coisas que nunca viveu, exagerar experiências. Naturalmente, a ausência das relações de controle explícitas da comunidade verbal também possibilita a emissão de respostas para o próprio indivíduo que seriam punidas se dirigidas a outros ouvintes, ou mesmo apenas sujeitas a extinção.

Decorre do autotacto o comportamento que podemos denominar autoinstrução, em que as respostas verbais autodirigidas esclarecem e categorizam elementos até que a resposta final seja emitida sob máximo controle de estímulo. $\mathrm{O}$ 
caderno em que um estudante faz apontamentos de pesquisa é um exemplo; as anotações facilitam a elaboração final do trabalho que ele deve produzir.

Sem nos estendermos detalhadamente, vale mencionar outras ocasiões importantes em que mandos e tactos dirigidos ao próprio indivíduo são reforçados por consequências práticas: as atividades ligadas à solução de problemas e à tomada de decisões, a racionalização, as resoluções pessoais.

Gostaríamos de resumir o que foi exposto até aqui sobre as relações entre pensamento e comportamento com uma citação de Skinner (1957, p. 445-446):

Uma conexão necessária entre pensamento verbal e autoestimulação, pode-se dizer, provém do fato de que, no mais estrito senso de nossa definição, qualquer comportamento que é reforçado porque modifica o comportamento subsequente do mesmo indivíduo é necessariamente verbal, independentemente de suas dimensões. O reforço é "mediado por um organismo", ainda que não estritamente outro organismo, e respostas que não têm as dimensões usuais de comportamentos vocal, escrito ou gestual podem adquirir algumas das características do comportamento verbal.

Respostas sem as dimensões usuais do comportamento verbal, às quais Skinner se refere na citação acima, podem ser, por exemplo, as encobertas. Podemos pensar em voz alta, mas em geral supõe-se que o pensamento seja um evento privado. Em todo o caso, quaisquer que sejam as dimensões do pensamento, ele será verbal à medida que o reforço das respostas que o compõem seja mediado pelas ações posteriores do indivíduo. Deste modo, o pensamento é sempre comportamento verbal? Responder afirmativamente é tentador, se nos concentramos em semelhanças formais; assim como o pensamento, o comportamento verbal pode ser encoberto e influenciar as atividades de um indivíduo de um modo aparentemente livre de restrições ambientais e temporais.

Entretanto, não é difícil encontrar exemplos em que a ideia de pensamento como uma categoria de comportamento verbal leva a um beco sem saída. Ao preparar o arranjo musical de uma obra, um intérprete pode começar dizendo a si mesmo, diante da partitura original, “Esta peça está em ré menor”, e então executar a 
melodia encobertamente (um comportamento não verbal) enquanto outras respostas (verbais) são emitidas, também de maneira privada, de modo que progressivamente o indivíduo produz o resultado final, com a definição das partes para cada instrumento a ser usado na execução pública e tudo o mais que em conjunto constitui o arranjo musical. Quando aprendemos a usar um aparelho a partir do manual de instruções e tentativas de operá-lo, ou quando descrevemos a solução de um problema através de respostas verbais, tenha a solução sido obtida através de comportamento verbal ou não, encontramos semelhanças formais com o que normalmente denominamos pensamento. Talvez, para arranjar uma canção, aprender a usar uma máquina moderna ou resolver um quebra-cabeça seja sempre preciso emitir respostas verbais, mas isso não prova que o pensamento é necessariamente verbal. Para retomar um exemplo anterior, "conversar com os seus botões" é comportamento verbal, mas fantasias visuais, que eventualmente são sustentadas pelas mesmas variáveis, não são:

Estava [Rubião] em uma longa cadeira de extensão, ermo do espírito, que rompera o teto e se perdera no ar. A quantas léguas iria? Nem condor nem águia o poderia dizer. Em marcha para a lua, - não via cá em baixo mais que as felicidades perenes, chovidas sobre ele, desde o berço, onde o embalaram fadas, até à Praia de Botafogo, aonde elas o trouxeram, por um chão de rosas e bogaris. Nenhum revés, nenhum malogro, nenhuma pobreza; - vida plácida, cosida de gozo, com rendas de supérfluo. Em marcha para a lua! (Machado, 1891, cap. 145, p. 147.)

Cremos que uma parte significativa do problema de ser ou não o pensamento necessariamente verbal reside na definição de eventos públicos e privados. A esse respeito, tomamos a liberdade de citar um extenso trecho de um artigo sobre o significado de eventos comportamentais relevantes para o behaviorismo radical:

Considere um participante experimental que foi exposto a uma contingência operante na presença de uma luz verde. Se a presença da luz verde agora ocasiona uma taxa de resposta mais alta do que em sua ausência, a luz pode estar funcionando como um estímulo discriminativo. A esta altura, poderíamos ser tentados a argumentar que o 
estímulo discriminativo é um evento público, porque tanto o sujeito quanto o experimentador (e qualquer outro que possa perceber uma luz verde) podem observar os eventos em questão. Tirar essa conclusão, entretanto, envolve confundir termos do senso comum com a nomenclatura científica da análise do comportamento. No primeiro caso, qualquer um que perceba a luz verde está observando a mesma luz verde, mas no segundo caso dois indivíduos jamais respondem ao mesmo estímulo discriminativo. Todo estímulo discriminativo dado adquire suas propriedades comportamentais no interior da história comportamental e do contexto atual de um organismo em particular. E porque não há duas histórias comportamentais que sejam exatamente idênticas, não há dois estímulos discriminativos que possam ser definidos, pelo menos tecnicamente, como o mesmo.... Neste sentido, portanto, dois organismos nunca respondem ao mesmo estímulo discriminativo, observam-no ou compartilham-no, e assim todos os eventos estimulativos em análise do comportamento são “privados" (Barnes-Holmes, 2003, p. 147-148).

Com isso, queremos dizer que não é importante distinguir entre eventos privados e públicos (ou respostas encobertas e abertas) para investigar o pensamento numa ciência fundamentada no behaviorismo radical. Em particular, para as finalidades desta dissertação, queremos sobretudo enfatizar uma relação entre a atividade de pensar e o autocontrole. Anteriormente, afirmamos que o autocontrole é modelado e mantido por conflitos entre reforçadores e punidores separados temporalmente e por contingências arranjadas pela comunidade verbal, e que as respostas controladoras não são obrigatoriamente verbais. Neste momento, argumentamos que os comportamentos que podemos denominar pensamento não devem ser assim distinguidos em termos formais, e interpretamos a análise proposta por Skinner (1957, cap. 19) - de que a atividade de pensar deve ser estudada como qualquer outra, isto é, em termos das relações funcionais que a determinam - de maneira a relacionar o pensamento ao autocontrole, como um conjunto de operantes que são selecionados na proporção da aptidão que conferem ao indivíduo para atuar sobre o ambiente físico e social de que faz parte: “Os homens são parte do mundo, e interagem com outras partes dele, inclusive outros homens" (Skinner, 1957, p. 451). 
Para melhor especificar, citamos Skinner (1989, p. 16): “Pensar é fazer algo que torna outro comportamento possível". A partir desta frase isolada, poderíamos lançar dúvidas sobre tal definição tão concisa. Afinal, isso seria apenas outro modo de descrever o que ocorre no encadeamento de respostas, e animais de várias outras espécies seriam portanto capazes de pensar; quando um rato, digamos, emite uma resposta que produz um estímulo discriminativo que evoca a emissão de outra resposta, sendo esta mantida por um reforçador incondicionado, sua atividade corresponderia topograficamente à definição de pensamento. A questão é difícil, uma vez que temos de apelar justamente para a topografia do "fazer algo" se queremos distinguir o que significa pensar em análise do comportamento.

Skinner (1989, p. 16) enumera o seguinte conjunto de atividades como exemplos de pensamento: expor, descobrir e detectar estímulos discriminativos que controlam outros comportamentos; observar, concentrar o olhar, considerar e contemplar até que o estímulo adquira força bastante para controlar outra resposta; procurar, esquadrinhar, explorar e planejar aumentam a chance de deparar-se com os estímulos relevantes; concentrar ou reunir diferentes estímulos aumentam o controle de contingências múltiplas; filtrar e discernir, pelo contrário, refinam o controle por dimensões específicas dos estímulos; marcar e distinguir mudam a probabilidade de ser controlado por determinados estímulos dentre vários; definir e determinar estabelecem limites para contingências de reforço; comparar e emparelhar ampliam a possibilidade de controle por uma dimensão que os estímulos compartilham; especular induz respostas de observação sob ângulos diferentes e mesmo contraditórios, que permitem a emissão de respostas controladas por dimensões relevantes; conjeturar, lançar ideias, aceitá-las e rejeitá-las manipulam diferentes respostas inicialmente sob fraco controle de estímulo e aumentam a chance de obter reforçadores à medida que multiplicam as opções de respostas; ponderar, deliberar e examinar traduzem uma modalidade de estimulação em outra, como ao transformar uma sensação de calor ou frio em graus de uma escala de temperatura; contar e calcular possibilitam respostas mais precisas em relação à intensidade dos estímulos; decidir e concluir importam à medida que interrompem as atividades de pensar e expõem o indivíduo às contingências subsequentes. 
A forma dessas atividades é bem distinta daquelas observadas nos encadeamentos que ocorrem em contingências naturais, e talvez não seja possível reproduzir em laboratório, com animais não humanos, todas as atividades que Skinner relaciona com o pensamento; no entanto, não é a forma uma distinção suficiente para considerar o pensamento ou o autocontrole tipos de comportamento que exigem um método de pesquisa substancialmente diferente daquele usado para analisar o comportamento operante. O pensamento e o autocontrole, em suma, diferem, em relação aos operantes em geral, quanto ao reforço ser frequentemente (ainda que não necessariamente) mediado, mesmo que o seja pelo próprio indivíduo, e pelas condições em que ocorrem serem fundamentalmente arranjadas pela comunidade verbal.

Essa exposição relativamente longa sobre o pensamento, do mesmo modo como afirmamos no fim da seção anterior, será relevante para entender o conceito skinneriano de eu e para sua comparação com James no próximo capítulo.

\section{3. $\mathrm{O}$ eu}

Skinner (1953, cap. 18) inicialmente sintetiza alguns fatos principais a respeito do eu. Primeiro, que é comum o eu ser usado como uma causa hipotética das atividades de um indivíduo, um agente interior que inicia e determina o comportamento. Em segundo lugar, que o eu é distinto do organismo: este comportase, aquele dirige a forma, intensidade e ocasião dos comportamentos. Finalmente, que mais de um eu seria necessário para explicar os diferentes comportamentos de um mesmo organismo (daí, por exemplo, a ideia de personalidades distintas ou de múltiplos aspectos de uma subjetividade que interagem na mente e cujo resultado se reflete nas atividades do indivíduo).

No behaviorismo metodológico, o eu é simplesmente excluído do campo de análise científica. Críticas a essa postura são abundantes desde a época em que John B. Watson publicava sua visão sobre psicologia e suas tentativas de relacionar o comportamento humano ao das outras espécies de maneira compatível com a teoria darwiniana de seleção natural (Skinner, 1959). Outra característica frequente das 
críticas é a confusão, deliberada ou inconsciente, entre a teoria de Watson e a análise do comportamento fundamentada no behaviorismo radical, como fica implícito, por exemplo, em Ades (1997) e Ribeiro (1997).

Cremos não ser necessário criticar a ideia de simplesmente excluir o eu do campo de investigação científica. Em vez disso, apresentamos diretamente o conceito de eu que Skinner (1953, p. 285) sugere: “um eu é simplesmente um dispositivo para representar um sistema de respostas funcionalmente unificado". Realmente, isso representa uma espécie de interdição às filosofias que procuram descrever os atributos fundamentais de algo que seja uma essência do eu; mas esse corte é útil para as necessidades impostas aos cientistas, necessidades que dizem respeito à identificação de variáveis independentes que funcionalmente determinam uma variável dependente - e sobretudo, que dizem respeito a evitar os riscos de atribuir à última o papel das anteriores. O eu (ou os eus), o que quer que seja, representa algo relacionado ao que um indivíduo faz, e esse algo, assim como o que o indivíduo faz, deve ser determinado por condições distintas do organismo - a não ser que partamos da noção de que há um criador interno, um originador de ações, uma suposição problemática por si mesma e que é, de todo o modo, antipsicológica.

Deste modo, o eu, para Skinner, é um termo que se refere a um modo de ação comum, identificado a subdivisões topográficas do comportamento. Essas divisões podem mostrar-se distintamente em diferentes situações, determinadas por estímulos discriminativos, privações, condições emocionais, efeitos de drogas. Daí ser comum observar, em um mesmo indivíduo, "personalidades" muito diferentes quando ele está num culto religioso ou num estádio de futebol, quando está há algum tempo sem comer ou fazer sexo, quando está comovido ou enfurecido, quando está bêbado ou sóbrio. Afinal, se o ambiente não é sempre o mesmo, não devemos esperar que o eu mantenha a mesma identidade ao longo do tempo. Também há ocasiões em que se apresentam ao indivíduo condições incompatíveis; por exemplo, uma pessoa pode assistir a uma missa realizada num estádio, ou estar faminto ao ir a um jantar romântico.

Outra característica importante do eu é a autoconsciência ou autoconhecimento. Seria melhor, em todo o caso, falar sobre as condições em que um 
eu pode ter consciência de outro eu ou conhecê-lo (ressaltando que os diferentes eus a que nos referimos dizem respeito ao mesmo indivíduo).

Quando surge uma ocasião em que provavelmente será reforçado um relato sobre o comportamento do próprio organismo, particularmente no nível encoberto, a personalidade que faz o relato é um especialista treinado por um conjunto especial de contingências. $\mathrm{O}$ eu que se ocupa do autoconhecimento funciona concorrentemente com o sistema comportamental que ele descreve (Skinner, 1953, p. 287-288).

Sob outra formulação: "Porque nosso comportamento é importante para os outros é que ele vem a se tornar importante para nós" (Skinner, 1957, p. 314). Quando se dirigem a um indivíduo perguntas simples como "O que você fez?", "O que está fazendo?”, “O que você pensa?”, “O que você sente?”, estabelecem-se condições para que ele adquira um repertório de autoconsciência. Conforme a comunidade verbal reforce, extinga ou puna tactos controlados pela estimulação decorrente das atividades do próprio indivíduo, o eu especialista em responder ao próprio comportamento pode configurar-se segundo uma enorme variedade de "níveis de autoconsciência", desde aquele observado entre os índios pirahãs (Everett, 2005) até o do narrador de No caminho de Swann (Proust, 1913).

\subsection{Adendo}

Chegamos ao final deste capítulo, e o que apresentamos sobre um possível conceito de $e u$ a partir do behaviorismo radical não se constitui como uma definição bem delimitada, ao contrário do que fizemos no capítulo dedicado à teoria de James. Enfatizamos aqui relações funcionais entre eventos ambientais e comportamentos tipicamente atribuídos ao eu. Antes, havíamos falado sobre o que é o eu. Aqui, falamos sobre como e por que o eu mostra-se como um fenômeno de interesse para a pesquisa em psicologia. No restante da dissertação, relacionaremos as duas concepções a fim de identificar semelhanças e diferenças entre as teorias psicológicas de James e Skinner sobre o eu, assim como propor itens para pesquisas posteriores. 


\section{4 \\ TRADUÇÃO DO CONCEITO DE EU}

Neste capítulo, traduziremos em termos behavioristas os constituintes do eu, os sentimentos e emoções por ele suscitados e as ações por ele incitadas. Falamos de tradução no mesmo sentido em que a palavra é usada nos Cadernos de Skinner (1980; o índice remissivo remete a 15 exemplos relevantes), em que o autor, em várias de suas breves anotações pessoais, comenta e reformula trechos de notícias e livros em termos científicos. Essa prática (ou sua necessidade) está longe de ter sido inventada por Skinner. James, ao falar sobre os métodos da psicologia, adverte:

A linguagem foi originalmente feita por homens que não eram psicólogos, e a maioria dos homens hoje empregam quase exclusivamente o vocabulário das coisas exteriores. As paixões cardeais de nossas vidas - raiva, amor, medo, ódio, esperança e as mais abrangentes divisões de nossas atividades intelectuais - lembrar, esperar, pensar, saber, sonhar - com os mais amplos gêneros de sentimentos estéticos alegria, lamento, prazer, dor - são os únicos fatos de uma ordem subjetiva que esse vocabulário digna-se notar com palavras específicas. As qualidades elementares da sensação, brilhante, alto, vermelho, azul, quente, frio, são, é verdade, suscetíveis de serem usadas tanto num sentido objetivo quanto subjetivo. Representam qualidades externas e os sentimentos que estas provocam....

Mas um defeito pior que a vacuidade [de termos científicos] decorre de depender a psicologia do discurso comum. Nomeando nosso pensamento por seus próprios objetos, quase todos nós supomos que assim como são os objetos, assim devem ser os pensamentos (James, 1890, p. 127-128).

A importância da linguagem na produção de explicações científicas em psicologia, especificamente em relação à análise do comportamento, permanece uma questão destacada, mais de um século depois da publicação dos Princípios de psicologia de James. Exemplos atuais de reflexões sobre o tema podem ser encontrados em Carone (2004) e Mechner (2008), assim como podem ser intuídos, em 
argumentos alinhados a uma certa forma de psicologia cognitiva, em Dawkins (2006) e Dennett (2005).

Para não nos estendermos desnecessariamente: buscamos produzir aqui uma comparação entre teorias compatível com a seguinte ideia de Skinner (1980, p. 141): "uma tradução é algo que tem o mesmo efeito sobre leitores de uma linguagem diferente que o texto tem sobre leitores da linguagem original".

\subsection{Eu material, filogênese e ontogênese}

Segundo James (1890), o eu material é o corpo do indivíduo e suas roupas, parentes próximos, casa, bens e objetos pessoais. Em análise do comportamento, podemos entender o primeiro item dessa série, o corpo, como o organismo considerado individualmente, cuja anatomia e fisiologia são determinadas filogeneticamente, características da espécie que resultam do processo de seleção natural. O que o organismo faz e pode vir a fazer depende diretamente de suas capacidades sensoriais e de promover mudanças no ambiente, assim como sua sensibilidade para ser afetado pelas consequências de suas ações no espaço em que vive. O corpo é a origem, por assim dizer, das necessidades biológicas do eu. Ou, em outras palavras, é da condição de ser um organismo que decorrem as motivações funcionalmente relacionadas ao seu comportamento individual: as privações e os estados corporais que acompanham as emoções.

Disto decorre um outro fator ligado à consideração do eu material em termos behavioristas: a ontogênese do comportamento. O corpo, em certo sentido, é sempre o mesmo, e igualmente está sempre em mudança, e o eu material, enquanto suporte da subjetividade, possui as duas características. $\mathrm{O}$ aspecto de permanência pode ser traduzido em termos de uma unidade de história de reforço, isto é, do entendimento de que o organismo atual resulta não só de uma história de seleção natural que o predispõe a ter certas características físicas e a agir de maneiras idiossincráticas, mas também de uma longa série de eventos em que as consequências de suas atividades o afetaram. O organismo presente é o único elemento comum, neste sentido, numa linha que se estende no tempo e na qual o indivíduo viveu em ambientes sempre 
cambiantes. $\mathrm{O}$ aspecto de permanência, entretanto, não se sustenta em condições físicas; o organismo não só muda no que diz respeito aos efeitos do envelhecimento, ele muda também como resultado das experiências que vive. As mudanças no organismo em função das experiências (ou, em outras palavras, da constante sucessão de estados de consciência) eram já uma suposição de James (1890, cap. 2-3), e as pesquisas em fisiologia têm produzido mais e mais evidências sobre as relações entre comportamento e as mudanças no organismo, em particular no sistema nervoso (Silva, Gonçalves \& Garcia-Mijares, 2007).

Desperta curiosidade saber por que James teria incluído no eu material elementos que à primeira vista caberiam melhor classificar sob a rubrica do eu social: roupas, parentes, casa, bens e objetos pessoais. São elementos que, afinal, diriam respeito ao controle do comportamento de outros indivíduos, não à caracterização da identidade em si. De fato, eles são condições determinantes na interação social, mas, no caso das roupas, algo do que James (1890, p. 188-189) afirma sobre o eu material apropriar-se delas como parte de sua identidade pode ser observado na caracterização inicial de Eugênio de Rastignac em O pai Goriot: “Usava ordinariamente uma velha sobrecasaca, um mau colete, a detestável gravata preta de estudante, enrugada e mal atada, calças em harmonia com o resto e sapatos consertados" (Balzac, 1834, p. 25). Mais adiante, o mesmo personagem sofre transformações significativas:

No momento em que o dinheiro escorre para dentro do bolso dum estudante, erguese intimamente nele uma coluna fantástica, sobre a qual se apoia. Caminha melhor que antes, sente que tem um ponto de apoio para sua alavanca, fica com o olhar cheio, reto, e os movimentos ágeis. Na véspera, humilde e tímido, deixaria que lhe batessem; no dia seguinte, ele próprio bateria num primeiro-ministro. Passam-se, nele, fenômenos extraordinários: tudo quer e tudo pode, deseja a torto e a direito, mostra-se alegre, generoso, expansivo. Numa palavra, o pássaro até então sem asas recupera sua envergadura. O estudante sem dinheiro apanha um bocado de prazer como um cão que furta um osso através de mil perigos, quebra-o, chupa-lhe o tutano e continua a correr; o rapaz que faz tilintar no bolso algumas fugitivas moedas de ouro degusta, porém, os prazeres, corta-os em pedacinhos, delicia-se com eles, 
embala-se no céu e já não sabe mais o que significa a palavra miséria. Paris inteira pertence-lhe (Balzac, 1834, p. 86-87).

Rastignac mora numa pensão miserável em Paris (sua família é de uma cidade do interior da França); não obstante, essa transformação permite que ele diga a si mesmo: “Ah! Se as mulheres de Paris soubessem... viriam fazer-se amar aqui!" (Balzac, 1834, p. 87). O dinheiro que permite sua metamorfose fora enviado por sua mãe e suas irmãs, a quem recorrera por carta em que dizia ter a oportunidade de enriquecer rapidamente desde que pudesse ter condições materiais suficientes para apresentar-se com dignidade na sociedade parisiense; roupas novas, por exemplo. Aplicando os princípios da análise do comportamento (seja em personagens literários, seja em pessoas de carne e osso), roupas, parentes, casa e posses dizem respeito a reforçadores e às oportunidades de obtê-los e defendê-los.

Roupas, parentes, casa e posses representam reforçadores de dois tipos, incondicionados e condicionados. Por um lado, é fácil observar que usar roupas é reforçado porque o organismo protege-se de condições ambientais eventualmente daninhas, como luz solar excessiva, ventos frios, espinhos de plantas, parasitas da pele, dentre vários exemplos possíveis; ser emocionalmente afetado pelo que acontece com parentes é selecionado filogeneticamente à medida que aumenta as chances da propagação das características do indivíduo ao longo das gerações; manter uma casa, de maneira semelhante às roupas, é reforçado enquanto garante um ambiente protegido das intempéries, em que se armazenam reforçadores (como mantimentos) e em que se pode desempenhar atividades sem a competição de outros organismos (como alimentar-se, repousar, procriar); objetos pessoais podem ter uma utilidade diretamente relacionada com a obtenção de reforçadores e à fuga ou esquiva de punidores (uma faca de pedra pode servir tanto para obter presas quanto para escapar de predadores). Por outro lado, seria difícil entender sob condições exclusivamente naturais por que as roupas têm certas cores, formas, materiais e adereços; por que alguns parentes são mais amados que outros ou por que agregados e membros adotados afetam o sujeito como se compartilhassem seu próprio sangue; por que as casas têm tamanhos, ornamentos e localizações de maneira muito 
independente de suas funcionalidades para o indivíduo; por que dinheiro e objetos pessoais são reunidos e buscados em quantidades e qualidades que estão além da necessidade e possível utilidade para um ser humano.

Roupas, parentes, casa e posses podem ser entendidos ao mesmo tempo como reforçadores incondicionados e como estímulos discriminativos (que equivalem, em sentidos específicos, a reforçadores condicionados). São partes do eu material, e podem ser objetos de investigação em análise do comportamento enquanto determinantes dos repertórios operantes que caracterizamos como típicos do sistema organizado de respostas que denominamos subjetivo. Em ambas as formulações, de James e de Skinner, podemos considerá-los como elementos que pertencem ao eu e de que o eu depende para ter sua identidade. No que diz respeito a sustentar essa afirmação em análise do comportamento, sugerimos como argumento exemplar o fato, amplamente registrado em condições experimentais, das reações emocionais observadas quando uma resposta frequentemente reforçada no passado é sujeita a extinção, reações que podemos descrever como frustração; prejuízos em qualquer dos elementos que James relaciona como pertencentes ao eu material significam, em termos behavioristas, não só a exposição do indivíduo a condições ambientais adversas, mas também (e talvez sobretudo) perder a chance de obter reforçadores que em última instância definem quem é o indivíduo ou quais são as relações funcionais que controlam o repertório comportamental que o define.

Em suma, o eu material de James pode ser traduzido, a fim de investigar as relações funcionais que o determinam, em termos de filogênese e ontogênese, de privações e emoções, e dos reforçadores envolvidos (tanto incondicionados quanto condicionados).

\subsection{Eu social e controle de estímulo}

O conceito de eu social em James descreve dois elementos: formas subjetivas e seus determinantes. Em outras palavras, refere-se a distintas topografias de comportamentos e às ocasiões que os evocam. Os dois aspectos são inseparáveis na teoria do próprio James (1890, p. 190): 
Muitos moços que são bastante maduros diante dos pais e professores praguejam e bravateiam como piratas entre seus jovens amigos "durões". Não nos mostramos a nossos filhos como a nossos companheiros do clube, a nossos clientes como aos trabalhadores que empregamos, a nossos próprios senhores e patrões como a nossos amigos íntimos. Disso resulta o que na prática é uma divisão do homem em diversos eus; e isso pode ser uma cisão discordante, como quando alguém tem medo de deixar que um conjunto de seus conhecidos saiba como ele é em outra situação; ou pode ser uma divisão de trabalho perfeitamente harmoniosa, como quando alguém terno com seus filhos é severo com os soldados e prisioneiros sob seu comando.

Tomamos da literatura um exemplo, dentre muitos possíveis, da grande diferença que pode haver entre os eus sociais de um indivíduo. No trecho a seguir, Brás Cubas conta que fazia reflexões variadas enquanto caminhava pelas ruas do Rio de Janeiro, e então:

Interrompeu-mas um ajuntamento; era um preto que vergalhava outro na praça. $\mathrm{O}$ outro não se atrevia a fugir; gemia somente estas únicas palavras: - “Não, perdão, meu senhor; meu senhor, perdão!" Mas o primeiro não fazia caso, e, a cada súplica, respondia com uma vergalhada nova.

- Toma, diabo! dizia ele; toma mais perdão, bêbedo!

- Meu senhor! gemia o outro.

- Cala a boca, besta! replicava o vergalho.

Parei, olhei... Justos céus! Quem havia de ser o do vergalho? Nada menos que o meu moleque Prudêncio, - o que meu pai libertara alguns anos antes. Cheguei-me; ele deteve-se logo e pediu-me a bênção; perguntei-lhe se aquele preto era escravo dele.

- É, sim, nhonhô.

- Fez-te alguma coisa?

- É um vadio e um bêbedo muito grande. Ainda hoje deixei ele na quitanda, enquanto eu ia lá embaixo na cidade, e ele deixou a quitanda para ir na venda beber.

- Está bom, perdoa-lhe, disse eu.

- Pois não, nhonhô. Nhonhô manda, não pede. Entra para casa, bêbedo! (Machado, 1881, cap. 68, p. 83.$)$ 
Voltaremos a Prudêncio mais adiante. Antes, é preciso dizer que ao considerarmos o significado do eu social em termos behavioristas, estamos tratando do conceito skinneriano básico desse objeto: "sistema de respostas funcionalmente unificado" (Skinner, 1953, p. 285). Quando falamos do eu social, estamos sobretudo no campo do controle de estímulo. As atividades de uma pessoa ou de um grupo, ou a simples apresentação deste ou daquela, são estímulos que controlam conjuntos inteiros de respostas de um indivíduo. No campo do comportamento verbal, isso pode ser entendido como o controle exercido pela audiência, que representa "uma condição para o reforço de um grande grupo de respostas e que portanto vem a afetar a força de tal grupo. Audiências diferentes controlam diferentes subdivisões do repertório do falante" (Skinner, 1957, p. 173).

James afirma que o eu social de um homem depende dos outros indivíduos, que “carregam uma imagem dele em suas mentes" (1890, p. 190). É desnecessário explicar por que, para um behaviorista, tal frase seria problemática. Ela é importante, aqui, na proporção em que representa um desafio interessante, tal como Mechner (2008, p. 242) afirma sobre a possibilidade de investigar, em análise do comportamento, a teoria do sistema de neurônios-espelho, mesmo que tenhamos de lidar com "uma representação, uma imagem ou um modelo internalizado". Mas como traduzir a imagem de que fala James em conceitos acessíveis aos procedimentos da análise do comportamento? Antes de tentar determinar o que seja essa imagem, buscaremos definir como ela determina o eu social.

A simples presença de uma pessoa pode eliciar condições emocionais, conforme o paradigma do condicionamento respondente, e o estado emocional decorrente predispõe o indivíduo a agir de certas maneiras e não de outras. Ao assistir às aulas de um professor que se assemelha ao pai devotado que um estudante teve, este se mostrará uma pessoa diferente do que no caso de seu pai ter sido opressor. Igualmente, a aparência de alguém diante de um indivíduo pode funcionar como estímulo incondicionado: uma mulher atraente pode fazer surgir um galanteador, e um homem musculoso pode levar ao aparecimento de um indivíduo submisso. Não só é possível que a aparência dos outros determine diferentes eus 
sociais, mas também as suas ações (ou sinais que indicam o que tenderão a fazer). Podemos aí incluir as expressões faciais dos outros tanto quanto a maneira como eles agem no ambiente. Uma diva que atira objetos contra as paredes ou um hércules que recita poemas líricos podem determinar eus sociais no indivíduo à sua frente bem diferentes do que sua mera aparência.

Estados emocionais, entretanto, são apenas uma parte dos determinantes do eu social, da "imagem" que o outro "carrega na mente". Em certo sentido, um estímulo condicionado continuar a eliciar respostas pavlovianas depende da participação de operantes, como a atividade de lembrar, por exemplo; afinal, a repetição do estímulo condicionado sem ser pareado com o estímulo incondicionado progressivamente leva à diminuição da magnitude (e eventual extinção) da resposta reflexa. A respeito da importância de abordar tanto respondentes quanto operantes ao investigar o controle de estímulo, citamos Skinner (1966, p. 652):

Uma análise cuidadosa das contingências de reforço tanto no comportamento operante quanto no respondente parece-me um primeiro passo absolutamente essencial. Não é um problema de diferenças na teoria, é uma questão de alcançar uma formulação que se adequa aos fatos conhecidos. Essa é uma tarefa à qual Pavlov, se estivesse vivo hoje, dedicar-se-ia com seu entusiasmo característico.

Outro aspecto dos determinantes do eu social está em serem a aparência e as atividades de outros indivíduos estímulos discriminativos que aumentam a probabilidade da emissão de respostas que caracterizam, topograficamente, um eu social dentre os diversos que podem ser apresentados por um mesmo indivíduo. É verdade que a exposição de um indivíduo a uma história de reforço determinada por contingências naturais eventualmente leva ao surgimento de repertórios específicos, controlados por estímulos do ambiente físico. Um homem solitário numa ilha deserta poderia mostrar-se, por exemplo, um coletor de frutos em certas épocas do ano, e poderia ser um caçador em outras ocasiões, conforme observasse sinais que indicam a presença de animais. Mas o controle de estímulo a que nos referimos aqui diz respeito a uma forma particular de modelagem e manutenção de comportamento, em que o reforço é mediado por outros indivíduos, as respostas não têm dimensões em 
comum com as consequências que as mantêm, e as contingências de reforço são arranjadas pela comunidade. Estas são as características distintivas do comportamento verbal, e também são características que parecem ser exclusivas da espécie humana, típicas das formas de controle do comportamento que fundamentam a produção e reprodução da cultura.

As "imagens" do eu que os outros "carregam na mente" são duradouras. Contingências de reforço social estabelecem operantes que tendem a apresentar uma maior resistência à extinção. Diante de contingências naturais, estímulos discriminativos, respostas e consequências interligam-se através de propriedades geométricas e mecânicas comuns entre as atividades do organismo e as características do ambiente, e em que há mais regularidade em comparação com o ambiente social. Mesmo em esquemas de reforço intermitente, respostas que perdem a eficácia em obter reforçadores incondicionados tendem a deixar de ser emitidas diante dos mesmos estímulos. Mas contingências sociais tanto envolvem estímulos, respostas e consequências que não têm dimensões comuns quanto estabelecem esquemas em que a probabilidade de reforço diante dos mesmos estímulos pode variar bastante. Por exemplo, um mesmo ouvinte pode estar num dia mais disposto a reforçar mandos do falante e, em outro dia, muito menos favorável. O controle do comportamento reforçado socialmente é, por assim dizer, mais "fluido" do que nas contingências naturais. É claro que não só o indivíduo é determinado, os outros também são. Falante e ouvinte alternam posições, assim como o indivíduo cujo comportamento analisamos e os indivíduos que medeiam os reforçadores das respostas daquele. Nos episódios em que contingências sociais ocorrem, o controle do comportamento é mútuo, isto é, a probabilidade de um indivíduo reforçar ou punir respostas do outro é dinâmica e não estática, e varia à medida que, no decorrer da interação entre os sujeitos, as respostas de um indivíduo alteram as variáveis que determinam as respostas do outro. Isso promove tanto uma maior resistência à extinção quanto uma maior variabilidade dos repertórios do indivíduo, além da possibilidade de submetê-los a discriminações mais sutis e a mudanças dramáticas na magnitude das respostas emitidas. 
De volta ao personagem Prudêncio (Machado, 1881, p. 83-84): ele mostra dois eus sociais distintos. O primeiro é o de um senhor, um proprietário de escravo; a tortura pública que aplica a seu servo é autorizada socialmente e, de fato, é reforçada não só pelos danos a ele infligidos mas também, e talvez sobretudo, pela aprovação das pessoas que assistem. Prudêncio é alforriado, tinha sido escravo doméstico do protagonista do romance; é razoável supor que sua história de vida, enquanto "moleque", tenha aumentado o valor reforçador de espancar uma pessoa semelhante. "Era um modo que o Prudêncio tinha de se desfazer das pancadas recebidas, - transmitindo-as a outro" (Machado, 1881, p. 84). O segundo eu social de Prudêncio é o mesmo da época em que seu senhor, Brás Cubas, "montava-o, punhalhe um freio na boca, e desancava-o sem compaixão" (Machado, 1881, p. 84). Não obstante ser agora um homem livre, o antigo amo dirigir-lhe a palavra faz ressurgir o servo, ainda que não dependa mais de sua mediação para obter reforçadores incondicionados, ou melhor, para escapar de estímulos aversivos incondicionados. Num momento, Prudêncio é um enérgico carrasco, e um segundo depois revela-se um dócil subordinado, para logo depois voltar a exercer sua condição de proprietário rigoroso.

Mas afinal como definir o que é a imagem do indivíduo que os outros carregam na mente, de que fala James? Ela é observada no comportamento do sujeito diante dos outros: é um repertório sob controle de estímulo, em contingências de reforço sociais. No que diz respeito ao "discurso" do eu social, trata-se do comportamento verbal controlado pela audiência. Para estudarmos o eu social em análise do comportamento, devemos investigar o controle de estímulo, tanto em termos de respondentes quanto de operantes.

Quando tratamos da tradução do eu material na seção anterior, afirmamos ser curioso como roupas, parentes, casa e posses foram classificados por James como partes daquele e não do eu social. Aqui, à medida que relacionamos o eu social ao controle de estímulo, somos obrigados a relacioná-lo à obtenção de reforçadores e, deste modo, a perguntar se não deveríamos inverter as classificações de eu material e social ou, ainda, fundi-las. Acreditamos não ser uma questão de deficiências na teoria de James: a distinção entre os constituintes do eu nos Princípios de psicologia ocorre 
por razões de utilidade na pesquisa científica. Afinal, “o Eu de um homem é o somatório de tudo que ele PODE chamar de seu" (James, 1890, p. 188).

O mesmo (falso) problema ocorreria se considerássemos exclusivamente os conceitos da análise do comportamento. Seria contrassenso pretender falar de estímulos discriminativos sem considerar respostas e reforçadores. Os três eventos podem ser descritos individualmente, mas não podem ser separados como objetos independentes entre si. Igualmente, nenhum dos termos que compõem as contingências de reforço teriam significado se ignorássemos a filogênese do organismo, privações, emoções e, especificamente no caso dos seres humanos, a comunidade verbal. A importância, para a pesquisa científica, de fazer distinções entre eventos psicologicamente relevantes, ao mesmo tempo que se mantém a integridade de suas relações funcionais, pode ser compreendida por exemplo num artigo seminal de Skinner (1931), “O conceito de reflexo na descrição do comportamento".

\subsection{Eu espiritual e comunidade verbal}

O eu espiritual pode ser, para James (1890, p. 191-197), adimensional, mas isso não significa que sua substância seja alguma espécie de éter, um tipo de matéria com propriedades especiais. Sua caracterização fundamental é o que o indivíduo reconhece como mais propriamente e mais intimamente seu. Sua consciência, suas cogitações, seu juízo, a percepção de si mesmo separado dos outros. São as

disposições psíquicas do indivíduo, em conjunto, que ele denomina suas, e a consciência de estar consciente; ocorrem no eu espiritual dois pensamentos lado a lado: o pensamento cujo objeto é aquilo sobre o que a consciência opera, e o pensamento cujo objeto é o próprio pensamento, reconhecido como exclusivamente pessoal. O eu espiritual, em outras palavras, constitui-se de consciência do mundo e consciência da consciência.

Nosso primeiro passo para traduzir o eu espiritual em termos behavioristas é notar que James refuta a ideia de uma possível substância para a consciência, ou de que ela possa ser considerada como algo estático. O pensamento é um fluxo (James, 
1890, cap. 9), uma sucessão de estados de consciência pessoais, cambiante, contínua, lidando com objetos independentes de si, e discriminativa. Identificamos, nesse caráter dinâmico da consciência segundo James, uma similaridade com as atividades do indivíduo que se comporta segundo Skinner: o organismo é um agente individual, emite diferentes respostas ao longo do tempo, é o elemento em comum numa história de reforço que se desenrola, opera sobre objetos do ambiente, e discrimina dimensões relevantes dentre tudo que está ao alcance de seu sistema perceptivo - em suma, características que se assemelham ao fluxo de pensamento de James. Sobre nenhum dos dois autores precisamos afirmar que a consciência pessoal, para um, ou o organismo como agente individual, para outro, são "criadores".

O eu espiritual, como referimos, implica a consciência. Considerá-lo tãosomente como o conjunto de disposições psíquicas, para James (1890, p. 191), significa descrevê-lo abstratamente. Porém, concretamente, o eu espiritual “será ou o inteiro fluxo de nossa consciência pessoal, ou o 'segmento' ou 'seção' presente desse fluxo" (James, 1890, p. 191). Para falar do eu espiritual em termos behavioristas e sob esses dois aspectos, abstrato e concreto, vamos inicialmente lançar mão do que dissemos no capítulo anterior sobre autocontrole e pensamento na teoria skinneriana.

O que seriam as disposições psíquicas? À primeira vista, essa ideia poderia ser simplesmente deixada de lado, enquanto explicamos as diferentes atividades de um indivíduo ao longo do tempo em termos de variáveis motivacionais, emoções e controle de estímulo. Em outras palavras, explicaríamos o comportamento do indivíduo conforme suas relações com o mundo "fora da pele", e essas relações dispensariam a ideia de haver processos intermediários "dentro da pele". Entretanto, a história de condicionamento social estabelece repertórios no indivíduo que resultam no que aparentemente são atividades que poderíamos relacionar ao assim chamado livre-arbítrio. O indivíduo emite respostas controladoras e deste modo manipula o momento de emissão das respostas controladas, assim como sua magnitude e ritmo, prioriza algumas em detrimento de outras, escolhe quais reforçadores obter dentre os disponíveis, antecipa punidores e prepara-se para evitálos ou suportá-los antes que se mostrem sinais que tipicamente os precedem - para citar algumas das várias formas possíveis de autocontrole. Aparentemente, o 
comportamento de um ser humano é livre da privação, por exemplo, quando marca uma hora para almoçar, usa uma balança para especificar quanto vai comer, conta as vezes que mastiga cada bocado, escolhe certos vegetais e rejeita certas carnes, repousa depois de alimentar-se e antes de exercer atividades físicas enérgicas. Esse indivíduo poderia dizer que faz tudo isso porque quer, porque isso é melhor para si, porque isso faz parte de suas crenças; ele assim declara-se responsável pela própria vida e um indivíduo livre. Os exemplos de comportamentos relacionados ao pensamento, como expusemos no capítulo anterior e obtidos de Skinner (1989, p. 16), podem ser agregados às formas de autocontrole de que falamos neste parágrafo para caracterizar, enfim, o que seriam as disposições psíquicas como "a parte do eu mais duradoura e íntima, a parte que nós mais verdadeiramente parecemos ser" (James, 1890, p. 191).

Segundo James, o eu espiritual, abstratamente, são as disposições psíquicas. Mas também é, concretamente, quem reivindica a posse dessas disposições, quem o afirma para si mesmo e para os outros. Como considerar essa ideia em análise do comportamento? Basicamente, em termos de respostas controladas por estímulos, privados ou públicos, gerados pelo comportamento do próprio indivíduo. (Antes de prosseguir, julgamos desnecessário enfatizar, a esse respeito, distinções entre eventos privados ou públicos, a partir da análise feita por Barnes-Holmes, 2003.)

A característica concreta do eu espiritual é que o indivíduo o sente como a sua identidade íntima:

Pois essa parte central do Eu é sentida.... não é em nenhuma medida um mero "ens rationis", cógnito somente através de uma maneira intelectual, nem uma mera soma de memórias ou um mero som de uma palavra em nossos ouvidos. É algo com que também temos contato sensível direto e que está tão integralmente presente em qualquer momento da consciência em que está presente quanto na duração total desses momentos. Quando, agora há pouco, foi chamado de abstração, aquilo não significava que, como alguma noção geral, não podia apresentar-se numa experiência particular. Apenas significava que no fluxo de consciência ele nunca era encontrado totalmente só. Mas quando é encontrado, é sentido; assim como o corpo é sentido, e o sentimento do corpo é também uma abstração, porque nunca se sente o corpo 
sozinho, mas sempre junto com outras coisas. Agora podemos nós dizer mais precisamente em que o sentimento desse eu central ativo consiste - não necessariamente, a esta altura, o que o eu ativo é, como um ser ou princípio, mas o que nós sentimos quando ficamos cientes de sua existência? (James, 1890, p. 193.)

Descrevemos o aspecto abstrato do eu espiritual como as atividades de autocontrole, sobretudo aquelas condicionadas pela comunidade verbal, e os comportamentos que classificamos como típicos do pensamento. Ao observarmos um indivíduo que exerce essas atividades, ele demonstra uma autonomia aparente. Podemos então declarar, a partir do que vemos "fora da pele" do indivíduo, que ele tem uma consciência pessoal, talvez um eu espiritual. Mas como ele observa as mesmas atividades? Ou, em outras palavras, teria ele consciência de sua aparente autonomia? Este é um campo em que facilmente pode-se cometer a falácia do psicólogo, expressão cunhada por James (1890, p. 128) para designar “a confusão de seu próprio ponto de vista com aquele do fato mental sobre que ele faz seu relatório". Declarar, assim, que o indivíduo demonstra um eu espiritual a partir do que vemos "fora da pele" é insuficiente, assim como seria o tratamento da consciência em terceira pessoa, ou heterofenomenológico, descrito por Dennett (2005, p. 25-56). O eu espiritual é sentido, vale repetir: afirmá-lo depende do próprio indivíduo ser capaz de identificá-lo ou descrevê-lo; em termos behavioristas, a condição para isso ocorrer é a presença de um eu "especialista treinado por um conjunto especial de contingências" (Skinner, 1953, p. 287) de que falamos no capítulo anterior, sobre a teoria behaviorista do eu. Esse especialista é um repertório de autoconhecimento que "funciona concorrentemente com o sistema comportamental que ele descreve" (Skinner, 1953, p. 287-288). A literatura nos dá uma pista dessas questões, na seguinte declaração do narrador de $A$ hora da estrela: "Pensar é um ato. Sentir é um fato. Os dois juntos - sou eu que escrevo o que estou escrevendo" (Lispector, 1977, p. 11).

Retomando a questão de James sobre o que o indivíduo sente quando reconhece a existência do eu espiritual, cremos que a resposta são os operantes verbais controlados pela estimulação resultante do comportamento do próprio indivíduo. Como exemplo desses operantes, citamos o próprio James (1890, p. 193): 
Antes de tudo, estou ciente de um constante jogo de facilitações e impedimentos em meu pensamento, de contenções e liberações, tendências que transudam desejo e tendências que vertem na direção oposta. Dentre os assuntos sobre os quais penso, alguns alinham-se no lado dos interesses do pensamento, enquanto outros desempenham um papel inamistoso em relação a eles. As inconsistências e concordâncias mútuas, reforços e obstruções, que subsistem entre esses assuntos objetivos, reverberam retroativamente e produzem o que parecem ser reações incessantes de minha espontaneidade sobre eles, acolhendo ou opondo-se, apropriando-se ou rejeitando, batendo-se a favor ou contra, dizendo sim ou não. Essa palpitante vida interior é, para mim, aquele núcleo central que acabei de tentar descrever em termos que todos os homens poderiam usar.

Em resumo, descrever e investigar o eu espiritual em análise do comportamento envolve pesquisar as contingências sociais que modelam e sustentam a maior parte dos operantes de autocontrole, assim como possibilitam o pensamento e o estabelecimento de repertórios controlados pela estimulação resultante do comportamento do próprio indivíduo. Em face disso, mais uma vez, como ao considerarmos o eu social em termos de controle de estímulo e o eu material em termos de obtenção de reforçadores, temos de ressaltar que a distinção entre material, social e espiritual na investigação do eu em análise do comportamento diz respeito aos interesses específicos de pesquisa de cada um dos aspectos desse objeto, e não a diferenças na natureza das variáveis que o determinam. Sociais ou naturais, trata-se sempre de contingências.

Novamente, a literatura pode fornecer exemplos sobre como entender o eu espiritual em termos da história de condicionamento social ou, em outras palavras, em termos da importância da vida em sociedade para a existência subjetiva. No romance $A$ hora da estrela (Lispector, 1977), o narrador revelou em variadas passagens o modo singular como a heroína da história sentia seu eu espiritual: 
Quero antes afiançar que essa moça não se conhece senão através de ir vivendo à toa. Se tivesse a tolice de se perguntar "quem sou eu?" cairia estatelada e em cheio no chão (p. 15).

Só uma vez se fez uma trágica pergunta: quem sou eu? Assustou-se tanto que parou completamente de pensar (p. 32).

A datilógrafa vivia numa espécie de atordoado nimbo, entre céu e inferno. Nunca pensara em "eu sou eu”. Acho que julgava não ter direito, ela era um acaso (p. 36).

Tinha o que se chama de vida interior e não sabia que tinha. Vivia de si mesma como se comesse as próprias entranhas (p. 37-38).

[Sobre seu nome, Macabéa explica:] - Eu também acho esquisito mas minha mãe botou ele por promessa a Nossa Senhora da Boa Morte se eu vingasse, até um ano de idade eu não era chamada porque não tinha nome, eu preferia continuar a nunca ser chamada em vez de ter um nome que ninguém tem mas parece que deu certo.... Pois como o senhor vê eu vinguei... pois é... (p. 43).

Agarrava-se a um fiapo de consciência e repetia mentalmente sem cessar: eu sou, eu sou, eu sou. Quem era, é que não sabia (p. 84).

\subsection{Ego puro e três níveis de seleção}

Ao longo de todo o capítulo “A consciência do eu”, James (1890, cap. 10) usa a palavra self para referir-se ao $e u$, em seus constituintes material, social e espiritual. Ego aparece apenas quando o autor fala sobre o princípio de identidade pessoal que em última instância corresponderia à subjetividade em si; daí o uso do qualificativo puro para designá-lo.

Como afirmamos no capítulo desta dissertação dedicado à teoria de James sobre o eu, o autor dos Princípios discute o ego puro sob três perspectivas filosóficas diferentes: espiritualista, associacionista e transcendentalista. Ele não adere a nenhuma dessas soluções, e denomina a sua própria de psicológica. Nas numerosas páginas que dedica ao ego puro, James expõe um debate entre três diferentes teorias filosóficas, por um lado, e uma teoria científica, por outro; vale lembrar que psicologia, para James, é uma ciência natural: 
Isto é, a mente que o psicólogo estuda é a mente de indivíduos distintos, habitantes de porções definidas de um espaço real e de um tempo real. Com qualquer outro tipo de mente, inteligência absoluta, mente desconectada de um corpo específico, ou mente não sujeita ao curso do tempo, o psicólogo como tal não tem nada a ver (James, 1890, p. 120).

Não procuraremos transpor em termos behavioristas as três teorias filosóficas que James reúne como paradigmas do ego puro. Isso envolveria considerações metafísicas que não pertencem ao campo delimitado para a pesquisa desta dissertação. Em vez disso: lembraremos que a solução de James para o problema do ego puro - quer dizer, o problema do que significa o princípio de identidade pessoal que perpassa e fundamenta todas as formas do eu - é a de relacioná-lo ao fluxo de pensamento; faremos uma citação das considerações finais de James sobre o ego puro e sua relação com a psicologia; então comentaremos (no espírito de "traduzir") as ideias que ali julgamos principais em termos compatíveis com a análise do comportamento.

Se alguém argumentar que eu não determino a razão por que os pensamentos sucessivamente passageiros deveriam herdar as posses uns dos outros, ou por que eles e os estados cerebrais deveriam ser funções (no sentido matemático) uns dos outros, eu responderei que a razão, se houver alguma, deve estar onde todas as razões reais estão, no total sentido ou significado do mundo (James, 1890, p. 259).

Agora, como "tradução" dessas palavras: o organismo emite respostas contínua e sucessivamente, e a estimulação resultante das respostas anteriores é parte das variáveis que determinam a forma, a magnitude e a frequência das respostas emitidas a cada momento; as consequências das respostas emitidas alteram o organismo, particularmente (quanto ao comportamento) em seu sistema nervoso, segundo relações funcionais empiricamente determináveis em termos quantitativos; a ideia subjacente a essas afirmações é a de há ordem nos eventos naturais.

Poderíamos ir mais além, no sentido de relacionar o princípio de identidade pessoal, representado pelo fluxo de pensamento, com a emissão contínua e sucessiva 
de respostas de autoconhecimento e autocontrole. Essas, por sua vez, são resultantes de três níveis de variação e seleção do comportamento (tal como descrito, por exemplo, em Skinner, 1990, p. 1206-1207): a seleção natural, o controle pelas consequências do comportamento no ambiente natural, e o condicionamento de operantes pela comunidade verbal.

\subsection{Sentimentos, emoções e ações do eu}

James (1890, p. 197-199) afirma que o eu suscita sentimentos e emoções, assim como incita ações, todos especificamente ligados à vida subjetiva do indivíduo. Para lembrar, os sentimentos e emoções suscitados pelo eu consistem na cenestesia, que se divide em duas classes, autocomplacência e autoinsatisfação; as ações incitadas pelo eu, decorrentes de "impulsos instintivos fundamentais" (James, 1890, p. 198), pertencem a dois conjuntos, autopreservação e autofavorecimento. Cremos que uma tradução desses conceitos em termos behavioristas levaria à repetição de ideias que apresentamos nas páginas anteriores. Tanto a cenestesia quanto a preservação e o favorecimento de si podem ser investigados, teórica e empiricamente, por meio de referências a contingências de reforço, tais como as que mencionamos ao longo de todo este capítulo. Sentimentos, emoções e ações típicas do eu são todos atividades, do ponto de vista da análise do comportamento, e sua especificação topográfica como algo distinto dos constituintes do eu teria pouco a oferecer no âmbito desta dissertação. Deste modo, por ora repetiremos o que Skinner (1986, p. 122) afirmou: “Existe provavelmente uma razão para a forma de cada palavra, assim como existe provavelmente uma razão para a cor de cada pássaro ou flor, mas não vale a pena procurar nenhuma delas como um fato específico".

É importante ressaltar, entretanto, que embora apliquemos aqui uma regra de parcimônia, não queremos dizer que não valeria a pena investigar - ou, pelo menos, traduzir em referências a contingências de reforço - termos como orgulho, vaidade, arrogância, modéstia, insegurança e mortificação, como alguns exemplos dos sentimentos e emoções citados por James, ou as ações que o autor relaciona à expressão de nossos "instintos" fundamentais. Para isso, a teoria e o método estão 
disponíveis em Comportamento verbal (Skinner, 1957); exemplos da tradução de termos psicológicos podem ser encontrados em "As origens do pensamento cognitivo" (Skinner, 1989); finalmente, uma reflexão ampla da natureza desses problemas acha-se em "A análise operacional de termos psicológicos" (Skinner, 1945).

Apenas para lembrar que as contingências a serem analisadas nesse âmbito não são simples, quer dizer, que esses comportamentos exigem a investigação de diversas variáveis numa relação complexa, citamos James (1890, p. 197):

Sem dúvida, quando estamos satisfeitos conosco, recitamos afetuosamente todas as possíveis recompensas segundo nosso merecimento e, quando num arroubo de desespero pessoal, pressagiamos o mal. Mas a mera expectativa de recompensa não é a satisfação consigo, e a mera apreensão do mal não é o desespero pessoal, pois há um certo matiz médio de cenestesia que cada um de nós carrega consigo, e que é independente das razões objetivas que podemos ter para estarmos satisfeitos ou descontentes. Isto é, um homem condicionado de modo muito reles pode abundar em presunção inquebrantável, e alguém cujo sucesso na vida é seguro e que é estimado por todos pode permanecer titubeante acerca de seus poderes até o fim.

Uma anotação de Skinner é relevante nesse contexto. Embora o behaviorista aluda à teoria de James e Lange sobre as emoções, o que ele comenta pode tanto mostrá-lo um pouco "titubeante" sobre suas ideias quanto ser um lembrete para estarmos abertos a interpretações flexíveis dos sentimentos, emoções e ações do eu, tal na identificação das variáveis envolvidas no controle múltiplo do comportamento, tal na consideração sobre o significado filosófico das experiências que compõem a existência humana:

Ao escrever "Humanismo e behaviorismo", eu afirmei: "Sexo não é reforçador porque sua sensação é boa; sua sensação é boa porque sexo é reforçador". Depois de enviar o artigo, percebi que tinha cometido o erro do qual acusara William James e enviei uma nota ao editor: Mude a frase para "é reforçador $e$ sua sensação é boa por uma razão filogenética comum". 
Mas mesmo isso omite algo. Chamamos coisas de boas quando são reforçadoras porque isso é, em parte, um meio de obter mais dessas coisas. Descrevemos reforçadores como bons, e coisas boas dão boas sensações, como dizemos. É importante não perder de vista a filogenia, mas ser reforçador e dar uma sensação boa não são exatamente cognatos (Skinner, 1980, p. 342). 


\section{5}

\section{JAMES E SKINNER: HEREDITARIEDADE E MUTAÇÃO}

No percurso de nossos argumentos, apresentamos um resumo das ideias de James e de Skinner sobre o eu, e propusemos uma interpretação dos conceitos jamesianos em termos compatíveis com o behaviorismo skinneriano. Neste capítulo, nossa intenção foi discutir relações entre o pensamento dos dois psicólogos, na forma de afinidades e divergências que se destacaram ao longo dos anos da pesquisa que resultou nesta dissertação e que se configuraram como evidências de que Skinner foi em certo sentido herdeiro de James e, por isso mesmo, alguém distinto dele. A reprodução, ao longo das gerações, não resulta em cópias, mas em variações, tal na evolução das espécies conforme a seleção natural, tal na evolução das culturas conforme a seleção pela comunidade verbal. Pretendemos falar de uma possível - e, para nós, provável - influência de James sobre Skinner.

Tratar de influências é uma operação intrincada e frequentemente árdua. Em geral, exige considerações historiográficas e comparações detalhadas entre os registros do comportamento verbal das pessoas envolvidas. Por exemplo, a investigação de como as influências ocorrem na ciência perpassa, de certa forma, toda a tarefa executada em A estrutura das revoluções científicas (Kuhn, 1970). Na obra Ciência e o mundo moderno (Whitehead, 1925, p. vii), a ideia está implícita na seguinte declaração, já no prefácio: "Este estudo guiou-se pela convicção de que a mentalidade de uma época brota da visão de mundo que é, de fato, dominante nos setores educados das comunidades em questão"; em seguida, os primeiros seis capítulos do livro mostram como essas mentalidades, desde o século 16, condicionaram o que veio a se configurar como a ciência do século 20.

Não só na ciência mas também na literatura é um trabalho rigoroso determinar ou sugerir influências. Gledson (2003, p. 32) comentou, a respeito do poeta de Itabira:

Seria fácil provar que Drummond foi "influenciado" por centenas de escritores: se nos guiássemos pelas menções nos poemas ou nas obras em prosa, quase não haveria 
fim para as possibilidades. Como Mário de Andrade disse a Drummond numa de suas cartas: "Em última análise, tudo é influência neste mundo". O que é mais difícil de determinar é quando ou até que ponto uma influência foi verdadeiramente criativa, ou revela aspectos importantes da personalidade dos autores envolvidos.

A esse respeito, identificar influências pode ser particularmente difícil no caso de um pensador para quem a ciência é "uma disposição para lidar com os fatos mais do que com o que alguém disse sobre eles" (Skinner, 1953, p. 12). As relações que sugeriremos neste capítulo não se baseiam em um método historiográfico nem em uma busca por similaridades topográficas entre as respostas verbais de James e Skinner. Etimologicamente, influência provém do verbo latino influo, para o qual o dicionário de Castiglioni e Mariotti (1966, p. 730) registra três acepções: a) escorrer, despejar-se, desaguar, desembocar; b) irromper, inundar, invadir; c) insinuar-se, penetrar. Neste capítulo, nossa discussão estará controlada pela última acepção, como na frase de Cícero que os autores do léxico dão como exemplo: "influere in aures contionis", isto é, "insinuar-se nos ouvidos da assembleia”. Quais estímulos verbais produzidos por James teriam configurado contingências de reforço para o comportamento de Skinner na comunidade de que ambos fizeram parte em diferentes períodos? Em todo o caso, não pretendemos responder a essa questão de maneira a esgotá-la.

Não seria difícil determinar influências de Watson e de Pavlov sobre Skinner; ele mesmo dá pistas a esse respeito, senão em outros lugares, em dois artigos dedicados àqueles cientistas $(1959,1966)$. Até onde sabemos, James não obteve de Skinner uma menção equivalente; entretanto, ele parece ter sido afetado, como ouvinte, pelo comportamento verbal de James. Dentro dos limites impostos a uma pesquisa de mestrado, e especificamente a partir do que apresentamos das teorias de James e Skinner sobre o eu, passamos agora a discutir algumas relações entre os dois cientistas, ou melhor, entre a análise do comportamento skinneriana e a psicologia jamesiana. 


\subsection{Eus múltiplos}

A primeira relação a considerarmos provém da ideia de James segundo a qual existem diferentes eus num mesmo indivíduo, distinguidos em constituintes (material, social, espiritual), assim como de acordo com os contextos em que está o indivíduo a cada momento. Disso decorre que os eus frequentemente rivalizam entre si, de modo que um deles se sobrepõe a todos os outros momentaneamente e que algumas de suas formas possíveis simplesmente se extinguem ao longo da história de vida do indivíduo. Nas palavras de James (1890, p. 199-200):

Muitas vezes sou confrontado pela necessidade de me alinhar a um de meus eus empíricos e abandonar o resto. Não que eu não seria, se pudesse, tanto bonito quanto gordo e bem vestido, e um grande atleta, alguém que ganha um milhão por ano, sagaz, um bon-vivant, e um sedutor irresistível, assim como um filósofo; um filantropo, estadista, guerreiro e explorador da África, assim como compositor de poemas sinfônicos e santo. Mas a coisa é simplesmente impossível. A obra do milionário correria na direção oposta à do santo; o bon-vivant e o filantropo tropeçariam um no outro; o filósofo e o sedutor não poderiam manter uma casa na mesma edificação de argila. Tão diferentes caracteres podem concebivelmente no início da vida ser igualmente possíveis para um homem. Mas para tornar qualquer deles real, o resto deve mais ou menos ser suprimido.

Cremos que uma ideia semelhante insinua-se nas páginas iniciais do capítulo sobre o eu de Ciência e comportamento humano (Skinner, 1953, cap. 18). Por exemplo, na frase "mais de um eu é preciso para explicar o comportamento de um organismo", ou em que "os mesmos fatos são comumente expressos em termos de "personalidades'" (Skinner, 1953, p. 284). É verdade que a discussão ali apresentada por Skinner não se harmoniza inteiramente com o que James afirmou, uma vez que o primeiro critica naquelas páginas iniciais a suposição de que esses diferentes eus são agentes causadores, algo que não corresponde a com que o segundo se ocupou em seu capítulo sobre o eu. O que mais nos parece relevante é a construção, pelo behaviorista, de uma organização de fatos estruturalmente similar à realizada por 
James. Afirmações como a seguinte, em nossa opinião, apontam para essa interpretação: “Duas ou mais personalidades podem aparecer em alternância ou concorrentemente. Elas com frequência estão em conflito umas com as outras, e uma pode ou não ter consciência do que a outra está fazendo" (Skinner, 1953, p. 284). Uma diferença importante, entretanto, surge em um texto bastante posterior: “O produto do condicionamento operante não é um repertório coerente único mas milhares de repertórios menores, e os conflitos entre eles devem de algum modo ser resolvidos" (Skinner, 1990, p. 1207); deste modo, os eus em Skinner não devem ser considerados como elementos, mas como populações ou espécies, sujeitas à dinâmica de variação e seleção pelo ambiente natural e sobretudo pela comunidade verbal. James descreveu os eus como elementos ou, digamos, espécimes; em todo o caso, assim como mencionou a variação e seleção de diferentes eus, ele talvez pudesse ter dado mais um passo e considerado os eus como Skinner o fez. É possível que definir o operante como unidade de análise tenha permitido ao behaviorista ter dado esse passo ao invés de James.

A ideia da sobreposição dos ambientes natural e social no controle do comportamento humano também parece demonstrar influências de James:

Uma certa quantidade de egoísmo corporal é requerida como base para todos os outros eus. Mas sensualidade demais é depreciada, ou no máximo condescendida por conta das outras qualidades do indivíduo. Os eus materiais mais amplos são considerados mais elevados que o corpo imediato.... O eu social como um todo, novamente, ocupa uma posição mais alta que o eu material como um todo. Devemos cuidar mais de nossa honra, nossos amigos, nossos laços humanos, do que de uma pele ou saúde firme. E o eu espiritual é tão supremamente precioso que, em vez de perdê-lo, um homem precisa estar disposto a desistir de amigos e boa fama, de propriedades, e da própria vida.

Em cada tipo de eu, material, social e espiritual, os homens fazem distinções entre o imediato e real e o remoto e potencial, entre a visão mais estreita e a mais ampla, em detrimento do anterior e em vantagem do posterior (James, 1890, p. 202-203). 
A citação revela igualmente uma ideia comum aos dois psicólogos: de que serem determinados a subjetividade (em James) e o comportamento (em Skinner) não significa que suas diferentes formas sejam produto do destino ou de condições fatalistas. Em outras palavras, enquanto a vida em sociedade determina e molda os diferentes eus e seus constituintes, a própria atividade dos eus faz parte dos determinantes de novas condições para sua existência. A ênfase de Skinner na utilidade da ciência para o controle das contingências a fim de produzir uma vida melhor aponta nessa direção.

Por outro lado, um tema recorrente em Skinner - que podemos sintetizar na frase: "A ciência cognitiva é a ciência criacionista da psicologia, à medida que luta para manter a posição de uma mente ou eu [criadores]" (Skinner, 1990, p. 1209) parece ser uma reação a certos argumentos de James (1890, p. 203-204):

De todos esses eus mais amplos, mais potenciais, o eu social potencial é o mais interessante, por causa de certos paradoxos aparentes a que conduz na conduta e por causa de sua conexão com nossa vida moral e religiosa. Quando, por motivos de honra e consciência, eu desafio a condenação de minha própria família, clube e "grupo"; quando, protestante, torno-me católico; católico, livre-pensador; "médico regular", homeopata ou o que for, sou sempre interiormente fortalecido em meu percurso e blindado contra a perda de meu eu social real pelo pensamento de outros juízes sociais possíveis melhores que aqueles cujo veredicto é contrário a mim agora.... Esse juiz é Deus, a Mente Absoluta, o "Grande Companheiro". Ouvimos, nesses dias de esclarecimento científico, uma grande quantidade de discussões sobre a eficácia da oração; e muitas razões nos são dadas sobre por que não devemos rezar, enquanto outras nos são dadas sobre por que devemos. Mas em tudo isso muito pouco é dito da razão sobre por que nós de fato rezamos, que é simplesmente a de que não conseguimos evitar rezar.... O impulso para rezar é uma consequência necessária do fato de que enquanto o mais íntimo dos eus empíricos de um homem é um Eu do tipo social, ele entretanto consegue encontrar seu único Sócio adequado num mundo ideal.

Mais adiante neste capítulo, teremos oportunidade de mostrar que James não pode ser alinhado a nenhuma forma de criacionismo, quando tratarmos da presença 
de Darwin na obra dos dois psicólogos. Por ora, queremos apenas mencionar que a baixa frequência de referências diretas de Skinner a James pode ter a ver com frases do segundo como as que acabamos de citar. Além disso, particularmente quanto a rezar, Skinner (1980, p. 82) revela uma posição bem menos favorável:

"Mesmo a palha sob meus joelhos gritava para distrair-me de minhas orações", diz Santo Agostinho (segundo John Steinbeck, em Boêmios errantes).

Poderia ser interessante buscar nas Confissões ou algum livro similar evidências de controle aversivo por uma agência religiosa. Homens "forçam-se" a rezar e a empenhar-se em obras pias para evitar as consequências do pecado ou impiedade. Daí a atribuição do mal à distração. Santo Agostinho rezando é como um estudante debruçado sobre um livro desinteressante.

\subsection{Consciência não é substância}

O capítulo de James (1890, cap. 10) que serve como fonte principal para nossa pesquisa intitula-se "A consciência do eu". Sobre o significado de "consciência" na psicologia jamesiana, gostaríamos de citar o penúltimo parágrafo do ensaio "A 'consciência' existe?" (James, 1912a):

Estou tão confiante quanto de qualquer outra coisa que em mim mesmo o fluxo de pensamento (que enfaticamente reconheço como um fenômeno) é somente um nome descuidado para o que, quando escrutinado, revela-se consistir mormente no fluxo de minha respiração. O "eu penso", sobre o qual Kant disse que deve poder acompanhar todos os meus objetos, é o "eu respiro" que de fato os acompanha. Há outros fatos internos além da respiração (ajustamentos musculares intracefálicos etc., dos quais eu disse algumas palavras em minha Psicologia mais ampla) e esses aumentam os ativos da "consciência" na proporção em que ela esteja sujeita à percepção imediata; mas a respiração, que sempre foi o original de "espírito", a respiração movendo-se para fora, entre a glote e as narinas, é, estou convencido, a essência da qual os filósofos construíram a entidade por eles conhecida como consciência. Essa entidade é fictícia, enquanto pensamentos, concretamente, são plenamente reais. Mas pensamentos, concretamente, são feitos da mesma matéria que as coisas são. 
A respiração "entre a glote e as narinas" é a fala, é uma das maneiras como o comportamento verbal é executado, e provavelmente foi sua primeira forma. Sobre os filósofos que consideram a consciência como uma entidade, James critica que eles tomaram a linguagem como a substância de que a consciência é feita. Um julgamento similar aparece em Skinner (1957, p. 446), em que ele menciona: “Alguma versão da doutrina foi ativamente proposta por behavioristas como uma solução do problema psicológico do conhecimento e por positivistas lógicos para seus próprios propósitos epistemológicos". Se todo o livro Comportamento verbal é bastante claro quanto à posição contrária de Skinner sobre o papel da linguagem proposto pelo behaviorismo metodológico e pelo positivismo lógico, o capítulo de que colhemos a citação, "Pensamento", é particularmente revelador. Discutimos, na seção correspondente de nosso capítulo sobre a teoria skinneriana do eu, os problemas de considerar o pensamento tão-somente como uma forma de comportamento verbal, e agora queremos apenas sugerir que essa postura reverbera a crítica feita anteriormente por James.

Talvez o uso que Skinner faz das palavras ficção e fictício - especificamente em expressões como ficção explicativa e causas fictícias - tenha sido controlado pela topografia das respostas verbais de James, como num comportamento ecoico; tal como substantivo, tal como adjetivo, o termo é usado em 16 páginas distintas ao longo de Ciência e comportamento humano (Skinner, 1953) para criticar explicações cientificamente espúrias. Talvez outros cientistas tenham usado a mesma palavra para refutar hipóteses lógica ou empiricamente; no entanto, por exemplo, Einstein (1905) usou outra, no artigo em que apresentou a teoria da relatividade restrita, para qualificar o postulado da existência do éter luminífero (que seria necessário para explicar a constância da velocidade da luz, empiricamente observada): supérfluo (überflüssig). Quem sabe Einstein tenha sido mais diplomático que James e Skinner, e pode ser que usar supérfluo ou fictício em vez de falso ou inútil seja irrelevante para traçar influências ao longo das gerações de pensadores além de qualificá-los individualmente como mais ou menos polêmicos ou delicados em relação às ideias alheias. 
O importante é destacar a enérgica refutação de James à conceituação da consciência como substância, autora ou proprietária de tudo que um indivíduo conhece ou pode conhecer. Essa mesma atitude é evidente ao longo de toda a obra skinneriana. Skinner não só repetidamente demonstrou com fatos o poder explicativo da análise do comportamento fundamentada no behaviorismo radical; ele também dedicou-se a apresentar os fatos sob a forma de contestações a explicações que supõem a existência de uma entidade etérea no interior do organismo.

Além disso, as relações fundamentais entre James e Skinner, aqui, consistem em o primeiro ter afirmado que respirar (dentre outras atividades fisiológicas do indivíduo) e pensar estão no mesmo nível de importância para a psicologia, e que pensamentos e objetos têm a mesma natureza (isto é, ambos pertencem à mesma categoria de eventos físicos). Pensar é uma maneira de comportar-se, assim como outras atividades do organismo, e comportar-se, assim como a existência dos seres vivos, é um evento dentre outros determinados no espaço e no tempo. A ênfase antidualista pode ser identificada na seguinte passagem de James (1890, p. 259):

Se o pensamento passageiro for o existente diretamente verificável que nenhuma escola até agora duvidou que seja, então esse pensamento é ele mesmo o pensador, e a psicologia não precisa olhar além. O único caminho que posso descobrir para introduzir um pensador mais transcendental seria o de negar que temos qualquer conhecimento direto do pensamento como tal. Esse último seria então reduzido a um postulado, uma asserção de que deve haver um conhecedor correlato a todo esse conhecido; e o problema de quem é esse pensador tornar-se-ia um problema metafísico.

\subsection{James e Skinner radicais}

James (1912b) acrescentou o adjetivo "radical" ao seu empirismo:

Dou o nome de "empirismo radical" à minha Weltanschauung [visão do mundo].... Para ser radical, um empirismo não deve admitir em suas construções nenhum elemento que não é diretamente experienciado nem excluir delas nenhum elemento que é diretamente experienciado. Para tal filosofia, as relações que conectam as 
experiências devem ser elas mesmas relações experienciadas, e qualquer tipo de relação que é experienciada deve ser considerada tão "real" quanto qualquer outra coisa no sistema. Os elementos podem de fato ser redistribuídos, a colocação original das coisas sendo corrigida, mas um lugar real deve ser encontrado para todo o tipo de coisa experienciada, seja termo ou relação, no arranjo filosófico final.

Esse modo de pensar fundamentou toda a sua psicologia; fica evidente, por exemplo, no capítulo “Os métodos e armadilhas da psicologia” (James, 1890, cap. 7) e em sua crítica à teoria associacionista do ego (James, 1890, p. 226-232), proveniente dos empiristas clássicos, que expusemos no capítulo desta dissertação sobre a conceituação jamesiana do eu. Mas o empirismo clássico não é o bastante para uma psicologia científica: James (1890, p. 227) usa um dito popular para afirmar, por exemplo, sobre Hume, que este joga fora o bebê com a água do banho quando afirma que o eu é a "diversidade abstrata e absoluta" - e, enquanto abstrata, fora de alcance empírico. Skinner não reivindica ter sido o responsável por acrescentar a qualificação "radical" ao termo "behaviorismo", e não procuramos localizar a origem dessa junção. Em qualquer caso, sua filosofia compartilha com a de James, além do adjetivo, um imperativo de que todas as explicações científicas devem pertencer ao mesmo nível ou categoria de fatos. A favor dessa interpretação ergue-se a rejeição de Skinner de referências a entidades ou eventos não físicos, ao longo de sua obra, para investigar o comportamento individual. A radicalidade proposta por James parece ter encontrado na análise do comportamento skinneriana um terreno fértil para desenvolver-se e transformar-se, onde, por exemplo, recebeu em acréscimo a ênfase no controle experimental e na quantificação das variáveis. Como fica claro em Skinner (1953, p. 53-54), ao comentar os experimentos de Pavlov:

Somente uma descrição quantitativa certificará que não há um processo mental adicional pelo qual o cão "associa o som da campainha com a ideia de alimento" ou pelo qual ele saliva porque "espera" que o alimento apareça. Pavlov pôde dispensar conceitos desse tipo somente quando pôde fornecer uma descrição quantitativa completa da salivação em termos do estímulo, da resposta e da história de condicionamento. 
Além disso, é no contexto do empirismo radical que James (1890, p. 121) declara as seguintes suposições como os dados irredutíveis da psicologia: 1) o psicólogo; 2) o pensamento estudado; 3) o objeto do pensamento; 4) a realidade do psicólogo.

Número 1, o psicólogo, acredita que os números 2, 3 e 4, que juntos formam seu objeto total, são realidades, e relata-os tão fielmente quanto pode, assim como suas relações mútuas, sem se incomodar em qualquer medida com o enigma de como ele pode relatá-los. Sobre tais enigmas de última instância ele essencialmente não precisa se incomodar mais que o geômetra, o químico ou o botânico, que fazem precisamente as mesmas suposições que ele (James, 1890, p. 121).

Em ambos, James e Skinner, a psicologia deve explicar tanto os estados de consciência ou o comportamento dos sujeitos estudados quanto os do próprio psicólogo (assim como um biólogo não pode pretender que suas declarações sobre os organismos não se apliquem a si mesmo). Um dos dois epílogos de Comportamento verbal, intitulado "A validade do comportamento verbal do autor" (Skinner, 1957, p. 453-456), é compatível com essa posição. E, sobre a atitude de não se incomodar com o "enigma" de como relatar os dados científicos, vale citar uma recomendação de Skinner (1990, p. 1209): “William James escreveu Princípios de psicologia no vernáculo. Behavioristas falam-no em suas vidas cotidianas (e jovens behavioristas devem aprender a fazê-lo sem embaraço)".

\subsection{Evolução da cultura}

James estava familiarizado com a obra de Darwin. Ele menciona-o não menos de 37 vezes em 10 capítulos distintos de Os princípios de psicologia. Na maior parte dessas referências, James comenta a teoria da evolução darwiniana e posiciona-se a seu favor, assim como a utiliza para sustentar suas próprias ideias - por exemplo, ao considerar como o sistema nervoso vem a relacionar-se funcionalmente com os estados de consciência e como se originaram os instintos (James, 1890, cap. 28). 
Podemos supor que essas menções seriam obrigatórias, já que desde o início James afirmou que a psicologia é uma ciência natural (e as proposições das diferentes disciplinas científicas devem ser compatíveis entre si, da física à psicologia, da química à biologia); de qualquer modo, ele também cita Lamarck e Spencer, em contraste com Darwin e claramente alinhando-se com o último. Num período em que a teoria da seleção natural ainda não tinha a seu favor os dados da genética moderna, James, ao contrário dos psicólogos do século 20, não seria obrigado a abraçar a interpretação darwiniana sobre a origem das espécies.

A presença de Darwin na psicologia skinneriana é evidente; a teoria da seleção natural é um dos fundamentos da filosofia do behaviorismo radical assim como da ciência do comportamento humano dela derivada. O que gostaríamos de aqui ressaltar é que James parece ter sido o precursor da ideia de que a sociedade evolui de maneira análoga aos processos de seleção que explicam a especiação em biologia e a modelagem das respostas operantes na ontogênese do comportamento individual. Num ensaio intitulado "Grandes homens, grandes pensamentos e o ambiente", publicado na revista The Atlantic Monthly, James (1880, p. 165) afirmou: "Um marcante paralelo, que eu penso nunca ter sido notado, subsiste entre os fatos da evolução social, por um lado, e da evolução zoológica tal como exposta pelo Sr. Darwin, por outro". A ideia correspondente em Skinner pode ser encontrada no seguinte excerto:

Vimos que em certos aspectos o reforço operante assemelha-se à seleção natural da teoria evolucionista. Exatamente como características genéticas que surgem como mutações são selecionadas ou descartadas por suas consequências, assim novas formas de comportamento são selecionadas ou descartadas através do reforço. Há ainda um terceiro tipo de seleção que se aplica a práticas culturais. Um grupo adota uma dada prática - um costume, um uso, um dispositivo de controle - seja por planejamento, seja por algum evento que, tanto quanto seu efeito sobre o grupo esteja envolvido, pode ser inteiramente acidental. Como uma característica do ambiente social, essa prática modifica o comportamento dos membros do grupo. O comportamento resultante pode afetar o sucesso do grupo na competição com outros grupos ou com relação ao ambiente não social. Práticas culturais que são vantajosas 
tenderão a ser características dos grupos que sobrevivem e que portanto perpetuam essas práticas. Pode-se portanto dizer que algumas práticas culturais têm valor de sobrevivência, enquanto outras são letais no sentido genético (Skinner, 1953, p. 430).

Faremos extenso uso dos argumentos apresentados por James no artigo de 1880 a fim de apresentar sua própria concepção e destacar afinidades e divergências com a ideia de evolução cultural de Skinner. O problema e uma sugestão para solucioná-lo são assim formulados por James (1880, p. 166):

Nosso problema é: quais são as causas que fazem as comunidades mudarem de geração a geração - que fazem a Inglaterra da rainha Anne tão diferente da Inglaterra de Elizabeth, o Harvard College de hoje tão diferente daquele de 30 anos atrás?

Tenho de responder: a diferença deve-se às influências acumuladas de indivíduos, de seus exemplos, suas iniciativas e suas decisões.

James assim enfatiza a importância do indivíduo e suas ações na evolução social; o modo como isso acontece ficará mais claro à medida que prosseguirmos. Mas uma frase sua, a respeito do desenvolvimento das ciências naturais, é uma chave relevante para compreender como o autor concebe o surgimento de novas ideias e práticas: “Toda concepção científica é em sua primeira ocorrência uma 'variação espontânea' no cérebro de alguém" (James, 1890, p. 863). Sempre vale ressaltar que uma variação espontânea é diferente da ação de um agente originador no interior do indivíduo ou de um primeiro motor na natureza. James, aliás, dedica boa parte do argumento para mostrar que podemos prescindir do debate sobre a origem das variações a fim de entender a evolução social como um processo paralelo ao da evolução das espécies segundo a seleção natural. Em suas palavras:

É uma platitude comum que o entendimento completo de qualquer coisa, por menor que seja, requereria o conhecimento do universo inteiro. Não cai um pardal no chão a não ser que algumas das condições remotas de sua queda sejam encontradas na Via Láctea, em nossa constituição federal ou na história antiga da Europa. Isto quer dizer: altere a Via Láctea, altere a constituição federal, altere os fatos de nossa ascendência 
bárbara, e o universo seria nessa medida um universo diferente do que é agora. Um fato envolvido na diferença poderia estar em que o pequeno menino de rua que atirou a pedra que pôs abaixo o pardal poderia não se encontrar diante do pardal naquele momento particular; ou, encontrando-se ali, ele poderia não estar com aquela disposição de espírito particularmente serena e despreocupada que se expressou em atirar a pedra. Mas, tão verdadeiro quanto tudo isso é, seria muito tolo, da parte de qualquer um que estivesse investigando a causa da queda do pardal, considerar o menino um agente por demais pessoal, próximo e, por assim dizer, antropomórfico, e afirmar que a verdadeira causa é a constituição federal, a migração ocidental da raça celta ou a estrutura da Via Láctea (James, 1880, p. 165).

Em outras palavras, para compreender a totalidade das causas que vêm a determinar cada fenômeno seria necessário uma mente infinita, onisciente. Seres humanos, que são limitados por sua condição finita e biológica, não podem assim pretender explicar todas as condições do universo que convergem para determinar as particularidades do objeto estudado. Isso não seria preciso, ademais, para entender um fenômeno. A teoria da seleção natural não requer a explicação de por que as variações acontecem; James (1880, p. 169-170) afirmou:

Existem, em resumo, diferentes ciclos de operação na natureza; diferentes departamentos, por assim dizer, relativamente independentes uns dos outros, de modo que o que acontece a qualquer momento em um pode ser compatível com quase qualquer condição das coisas ao mesmo tempo no outro....

Se olhamos um animal ou um ser humano, distinto do resto de sua espécie pela posse de alguma peculiaridade extraordinária, boa ou má, temos de ser capazes de discriminar as causas que originalmente produziram a peculiaridade nele e as causas que a mantêm depois que é produzida; e veremos, se for uma peculiaridade com a qual ele nasceu, que esses dois conjuntos de causas pertencem a tais dois ciclos irrelevantes. Foi a originalidade triunfante de Darwin que viu isso e agiu de acordo. Separando as causas da produção sob o título de "tendências de variação espontânea" e relegando-as a um ciclo fisiológico que ele sem demora concordou em ignorar totalmente, ele confinou sua atenção às causas da preservação, e sob os 
nomes de seleção natural e seleção sexual estudou-as exclusivamente como funções do ciclo do ambiente.

O importante é o modo como as consequências determinam a forma das respostas e sua probabilidade de emissão, e não a origem das atividades de exploração típicas do rato, das bicadas de um pombo em objetos coloridos e luminosos, ou das vocalizações espontâneas de uma criança. A explicação deve concentrar-se nos efeitos do ambiente sobre as atividades dos indivíduos:

[O verdadeiro problema com que temos de lidar quando estudamos os efeitos do ambiente sobre o animal] é simplesmente o seguinte: o ambiente mais provavelmente preserva ou destrói o animal, por conta dessa ou daquela peculiaridade com que ele pode ter nascido?... O que Darwin quer dizer é que, uma vez que o ambiente é uma coisa perfeitamente conhecida e suas relações com o organismo na forma de destruição ou preservação são tangíveis e distintas, traria uma completa confusão a nossas compreensões finitas e uma completa frustração a nossas esperanças científicas misturar nisso fatos de um ciclo tão destoante e incomensurável como o daquele em que as variações são produzidas (James, 1880, p. 171).

Talvez o programa do behaviorismo radical tenha herdado dessa atitude de James, que acabamos de citar, a sua ênfase às contingências de reforço, sem lançar mão, por exemplo, da ideia de que o sistema nervoso origina comportamentos (Skinner, 1953, p. 27-29). De todo o modo, queremos destacar agora o salto proposto por James, da explicação das características dos organismos conforme a seleção natural para a explicação da existência de indivíduos notáveis na sociedade:

As causas da produção de grandes homens residem numa esfera inteiramente inacessível ao filósofo social. Ele deve simplesmente aceitar os gênios como dados, exatamente como Darwin aceita suas variações espontâneas. Para ele, assim como para Darwin, o único problema é, apresentados esses dados: como o ambiente os afeta e como eles afetam o ambiente? Agora, afirmo que a relação do ambiente visível com o grande homem é, em todos os pontos principais, exatamente a mesma relação com a "variação" na filosofia darwiniana. O ambiente especialmente adota ou rejeita, 
preserva ou destrói, em resumo, seleciona-o. E sempre que adota e preserva o grande homem, modifica-se devido a sua influência de um modo inteiramente original e peculiar (James, 1880, p. 173).

James enfatiza a importância dos grandes homens na evolução da sociedade, ao mesmo tempo que discute como o ambiente social permite que eles floresçam ou minguem. A ênfase jamesiana nos gênios corresponde a uma relevante divergência de Skinner a esse respeito. O behaviorista afirmou, por exemplo:

Em suas Conversas com professores, William James insistiu que não havia nada de errado com o sistema escolar americano que não pudesse ser corrigido com “impregná-lo com gênios”. É uma velha fórmula: se você não consegue resolver um problema, ache alguém que consiga. Se você não sabe ensinar, encontre alguém que saiba ou que possa descobrir sozinho. Mas o estoque de gênios é escasso, e bons professores não vêm pré-fabricados (Skinner, 1963, p. 243).

Sem dúvida, é uma divergência importante, a que voltaremos em seguida. Antes, queremos reafirmar a afinidade entre James e Skinner quanto à interação entre as ações dos indivíduos e sua seleção social na determinação da evolução da cultura:

Assim, a evolução social é resultante da interação de dois fatores inteiramente distintos - o indivíduo, derivando seus dons peculiares do jogo de forças fisiológicas e infrassociais, mas carregando todo o poder de iniciativa e originalidade em suas mãos; e, em segundo lugar, o ambiente social, com seu poder de adotar ou rejeitar tanto o indivíduo quanto seus dons. Ambos fatores são essenciais para a mudança. A comunidade estagna sem o impulso do indivíduo. O impulso mingua sem a empatia da comunidade (James, 1880, p. 178).

Lembrando que o "poder de iniciativa e originalidade" (1880, p. 178) do indivíduo decorre, para James, de “uma 'variação espontânea' no cérebro" (1890, p. 863), e que em Skinner aquela ideia pode ser cientificamente interpretada na proporção em que se conhece a história de condicionamento do indivíduo, julgamos 
ter destacado o bastante a afinidade entre os dois psicólogos quanto à ideia de evolução da sociedade (ou da cultura). Parece-nos, de todo o modo, que James não discutiu decisivamente o modo como as consequências das ações dos indivíduos determinam sua preservação ou supressão ao longo das gerações. A teoria skinneriana, neste sentido, pôde avançar significativamente, a partir dos dados experimentais acumulados ao longo da investigação do comportamento operante, verbal ou não. É diante desse quadro que voltamos à divergência entre James e Skinner quanto à importância dos gênios na sociedade. Talvez as considerações do segundo, quase no fim do livro Comportamento verbal, reverberem criticamente a afeição do primeiro ao papel dos gênios:

É uma salutar consequência desse ponto de vista aceitar o fato de que os pensamentos dos grandes homens são inacessíveis para nós hoje. Quando estudamos grandes obras, estudamos o efeito sobre nós dos registros sobreviventes do comportamento dos homens. É o nosso comportamento com respeito a tais registros o que observamos; estudamos nosso pensamento, não o deles (Skinner, 1957, p. 452).

Assim, o behaviorismo radical e a análise do comportamento skinneriana, em nossa opinião, dão um passo além do empirismo radical e da psicologia jamesiana não só quanto a terem à sua disposição um importante acúmulo de dados científicos sobre os determinantes do comportamento mas quanto à atitude de intervir na sociedade. O capítulo "Planejando uma cultura", de Ciência e comportamento (Skinner, 1953, cap. 28), é um exemplo dentre os vários textos em que o behaviorista toma essa posição e a inclui como parte essencial do programa da análise do comportamento. James talvez tenha sido a fonte que influenciou Skinner a falar sobre evolução da cultura, mas enquanto o primeiro deixou de lado as considerações sobre a origem das variações que são preservadas ou suprimidas pela sociedade ao longo de sua evolução, o segundo estendeu a possibilidade de explicar também essas variações e, deste modo, atuar sobre as variáveis independentes que funcionalmente as determinam a fim de produzir um mundo melhor, natural e social, para os indivíduos - tanto para os gênios quanto para os homens e mulheres comuns. 


\section{CONCLUSÃO}

\subsection{O amor aos fatos}

Numa reflexão sobre as origens da ciência moderna, Whitehead $(1925$, cap. 1) afirmou que o desenvolvimento da ciência recoloriu nossa mentalidade. A esse respeito, em suas palavras:

A nova mentalidade é ainda mais importante que a nova ciência e a nova tecnologia. Ela alterou as pressuposições metafísicas e os conteúdos imaginativos de nossas mentes; de modo que agora os velhos estímulos provocam uma nova resposta. Talvez minha metáfora de uma nova cor seja forte demais. O sentido é apenas aquela sutílima mudança de tom que no entanto faz toda a diferença. Isso é exatamente ilustrado por uma sentença em uma carta publicada daquele gênio adorável, William James. Quando estava finalizando seu grande tratado sobre os Princípios de psicologia, ele escreveu a seu irmão, Henry James: “Tenho de forjar cada sentença nas garras de fatos irredutíveis e obstinados".

Esse novo matiz das mentes modernas é um interesse veemente e apaixonado pela relação entre princípios gerais e fatos irredutíveis e obstinados.... Esse equilíbrio mental tornou-se agora parte da tradição que infecta o pensamento culto. É o sal que mantém a vida doce (Whitehead, 1925, p. 2-3).

Não é difícil enxergar que James e Skinner estiveram impregnados desse "sal que mantém a vida doce". James era fisiólogo tanto quanto filósofo e psicólogo, e nunca abriu mão da coerência ao expor suas teorias em todas as áreas para as quais dirigiu suas finas habilidades intelectuais. Skinner, é uma redundância afirmar, pertenceu à mesma linhagem de indivíduos que compartilharam a mentalidade a que se refere Whitehead.

Entretanto, cremos que dizer de ambos que estavam impregnados desse sal é uma metáfora incompleta, senão injusta. Afinal, quando impregnamos de sal um objeto, ele se torna estéril. É uma maneira de conservar carne, por exemplo, assim 
como um modo de impedir que um terreno seja propício à vida; sempre no campo da metáfora, é um jeito de estender bênçãos e de declarar maldições. Quão salgados teriam sido James e Skinner? Quão determinados por essa mentalidade, por essa paixão veemente pelos fatos, eles teriam sido?

Naturalmente, usamos a palavra mentalidade de um modo pouco rigoroso. Ela quer dizer, aqui, um conjunto de contingências de reforço que selecionam formas específicas de comportamento; contingências em que, dentre outros eventos, a emissão de tactos metaforicamente estendidos (hipóteses científicas, por exemplo) é condicionalmente reforçada até que a eficácia dessas respostas verbais em interpretar, prever e produzir um determinado fenômeno seja testada, isto é, até que consequências naturais venham a extingui-las, modificá-las ou estabelecer a dimensão relevante do objeto estudado como um estímulo discriminativo que controla a emissão das respostas, que neste ponto não são mais extensões metafóricas, mas, digamos, tactos puros (Skinner, 1957, cap. 18). Particularmente: “práticas experimentais podem nos permitir isolar essa propriedade... e deste modo substituir a metáfora por uma resposta abstrata" (Skinner, 1957, p. 428).

Cremos que é bastante apropriada a frase de James citada por Whitehead a respeito de sua atitude em psicologia. Seus Princípios, por exemplo, revelam uma busca constante por relacionar a teoria psicológica ao que se conhecia na época sobre a fisiologia do sistema nervoso; mas, ao mesmo tempo, representam um debate com o que denominamos aqui de psicologia filosófica. Por um lado, James foi um dos precursores mais significativos da psicologia moderna ou científica; sua obra surge no mesmo período em que na Europa acumulavam-se dados empíricos obtidos em laboratório pelos pesquisadores da psicofísica, por exemplo. Neste sentido, uma formulação ampla dos princípios gerais da "nova" ciência era requerida, tal como James realizou. Por outro lado, aparentemente era também necessário dar conta de relacionar criticamente a teoria com as ideias provenientes da filosofia a respeito dos fenômenos psicológicos, propostas e debatidas havia milênios. Talvez essa seja a razão por que James não pôde abandonar, por exemplo, a ênfase na assim chamada "vida interior" da mente - é verdade que ele pôs abaixo a ideia da consciência como 
uma substância, mas em certo sentido o conceito de fluxo de pensamento veio ocupar o lugar da mente como entidade.

De todo o modo, em nossa opinião, a obra de James representa o contexto especificamente psicológico a partir do qual Skinner desenvolveu a sua própria psicologia - sem subestimar, é claro, Darwin, Watson e Pavlov como fontes principais na formação do pensamento skinneriano. A favor da opinião que aqui lançamos, estão as similaridades entre James e Skinner na organização estrutural do eu como tema de pesquisa e na facilidade com que pudemos traduzir os conceitos jamesianos sobre esse objeto em termos familiares à análise do comportamento.

Seria ótimo poder considerar Whitehead como o termo médio de um silogismo que ligasse James a Skinner. Isso no entanto é impossível. Não parece haver evidências de que Whitehead tenha tido contato com James, além de provavelmente ter estudado algo de suas ideias, e seu contato com Skinner aparentemente pode ser resumido no episódio do escorpião negro que não caía sobre a mesa em que ambos acabaram de jantar (Skinner, 1957, p. 456-460). Como afirmamos em outro momento, nossa pesquisa não lançou mão de métodos historiográficos nem de comparações topográficas de registros de comportamento verbal. Nosso argumento baseia-se na comparação das realizações filosóficas e científicas dos pensadores que estudamos. É sob essa condição, igualmente, que não estenderemos esse raciocínio para abranger outro cientista, que talvez pudesse fazer o papel de termo médio entre James e Skinner de maneira mais verossímil: Thorndike, que foi orientado por James (Britannica, 2003), e cujas considerações teóricas foram tão importantes para as primeiras pesquisas de Skinner na mesma Universidade Harvard.

James e Skinner, enfim, eram ambos veemente e apaixonadamente interessados nos fatos. Em algum momento, talvez pudessem dizer, ecoando o narrador de A hora da estrela: "Estou me interessando terrivelmente por fatos: fatos são pedras duras. Não há como fugir. Fatos são palavras ditas pelo mundo" (Lispector, 1977, p. 71). 


\subsection{A psicologia e as outras ciências naturais}

Essa paixão por relacionar princípios gerais aos fatos empíricos, de todo o modo, não se manteve viva em todas as escolas psicológicas posteriores ao longo do século 20. Um caso curioso ocorre com a denominada psicologia cognitiva. Dentre os vários princípios que James estabeleceu como fundamentos para a pesquisa psicológica, está a firme rejeição da ideia de que a consciência tem uma substância cognitiva. Em meio a seus argumentos, ele afirma: "A concepção da consciência como uma forma de ser puramente cognitiva, que é a maneira favorita de considerála em muitas escolas idealistas, modernas assim como antigas, é completamente antipsicológica" (James, 1890, p. 92). Não obstante, a assim chamada revolução cognitiva do meado do século 20 baseia-se na ideia mesma que o psicólogo demonstrara inválida nos Princípios, de que consciência é cognição. A palavra revolução parece em certo sentido bastante adequada, se a entendermos como o retorno a um ponto de partida que fora abandonado há tempos.

Por outro lado, a predileção pelos fatos manteve-se e ampliou-se em Skinner. A psicologia científica decorrente da filosofia do behaviorismo radical, aliás, em nossa opinião, avançou nessa atitude em comparação com Os princípios de psicologia. Para James, os fenômenos psicológicos podiam sempre ser relacionados a eventos que ocorrem no sistema nervoso dos indivíduos. Embora isso represente no mínimo uma correlação entre os fatos da psicologia e da fisiologia, isto é, uma constatação de que a teoria de James é compatível com outras ciências naturais, o fluxo de pensamento como objeto da psicologia exige, para sua caracterização, um procedimento semelhante ao método de introspecção, ainda que bastante distinto dele. Por exemplo, no segundo parágrafo do capítulo "O fluxo de pensamento":

O primeiro fato para nós, então, como psicólogos, é que pensamento de algum tipo ocorre. Uso a palavra pensamento... para toda a forma de consciência indiscriminadamente. Se pudéssemos dizer em inglês "pensa", como dizemos "chove" ou "venta", deveríamos afirmar o fato da mais simples maneira e com o mínimo de suposições. Como não podemos, devemos simplesmente dizer que pensamento ocorre (James, 1890, p. 146). 
É sempre um indivíduo quem pensa, e ele é testemunha dos seus estados sucessivos de consciência. Já o programa do behaviorismo radical propõe, em lugar do fluxo de pensamento, o comportamento individual como objeto básico da psicologia. Isso possibilita, por exemplo, que o psicólogo possa escapar do problema que Skinner denominou "geografia da mente" (1969, p. 265): “Uma das coisas mais absurdas sobre o mundo da mente é o espaço que ela ocupa. É um mundo interior e assim é observado através de introspecção, mas olha-se para os próprios pensamentos com um órgão até agora inidentificado". Deste modo, a análise do comportamento garante uma maior compatibilidade com as outras ciências naturais, como a física, por exemplo, em comparação com a psicologia jamesiana. Ademais, graças a isso, até mesmo dados provenientes de disciplinas científicas fundamentadas em correntes teóricas diferentes do behaviorismo radical podem ser incorporados na análise, como se pode observar nos fatos reunidos, por exemplo, em Silva et al. (2007), e como somos convidados a fazer por Mechner (2008).

\subsection{A suposta morte da psicologia jamesiana}

No segundo parágrafo do ensaio "Um mundo de pura experiência", James (1912b) declara sua atitude em relação à comunidade filosófica e científica:

Proponho... lançar minha descrição no ebuliente tanque de fermentação do público, onde, confrontada por rivais e dilacerada por críticos, eventualmente desaparecerá de vista, ou ainda, se melhor sorte recair sobre ela, submergirá calmamente nas profundezas e servirá como possível fermento de novos desenvolvimentos ou núcleo de uma nova cristalização.

Para nós é notável como James não é uma referência frequente no ensino de psicologia e nos debates e considerações teóricas a respeito da disciplina. É verdade que às vezes encontramos estudos que mencionam suas ideias sob o ponto de vista do interesse histórico (por exemplo, Abib, 1996, 1999), mas mesmo em alguns estudos especificamente voltados à história da psicologia acontece de James ser simplesmente ignorado, como em Figueiredo (1992) - ainda que em outra obra do 
mesmo autor James apareça como precursor da assim chamada matriz funcionalista na psicologia americana, e seu pensamento seja ligado “à tradição estrutural derivada da filosofia de Kant" (Figueiredo, 1991, p. 79). Quem sabe, James não foi claro o suficiente quanto ao que pensava de Kant quando denominou o ego transcendental de "edição 'reles e barata' da alma" (1890, p. 235). Em todo o caso, a amostra de textos que usamos no argumento deste parágrafo é pequena; é importante ressaltar que expressamos aqui uma nossa impressão.

E nossa impressão, depois de conhecer um pouco da obra de James, é a de que seus Princípios interessam não tanto como história quanto como um meio de tratar dos problemas fundamentais da psicologia, em qualquer das várias escolas que a compõem ou das disciplinas cujos campos de pesquisa se sobreponham parcialmente a ela. A favor dessa ideia, mencionamos não só a abrangência dos temas sobre os quais James versou, mas principalmente o rigor da análise realizada pelo autor, sempre fiel aos "fatos irredutíveis e obstinados", como na frase citada por Whitehead (1925, p. 3). Para um analista do comportamento, por exemplo, os Princípios oferecem não só uma descrição dos variados fenômenos com os quais ocupa-se a psicologia "tradicional", mas todo um vocabulário com que se pode dialogar com pesquisadores de outras ciências e até mesmo com o público leigo, além de representar uma fonte de temas a pesquisar - principalmente porque as ideias de James prescindem de suposições problemáticas como, por exemplo, da consciência como substância.

E talvez seja por isso mesmo - por criticar e dispensar suposições inadequadas para a pesquisa científica - que James seja hoje uma presença rara na formação dos psicólogos e nos debates sobre a disciplina. O comportamento de não emitir respostas verbais que são punidas pela comunidade de que o indivíduo faz parte é reforçado; os cientistas não estão livres dessas contingências; e comunidades que punem respostas controladas pelo "interesse veemente e apaixonado pela relação entre princípios gerais e fatos irredutíveis e obstinados" (Whitehead, 1925, p. 2) são ainda abundantes, como relata Dawkins (2006, cap. 8).

A suposta morte da psicologia jamesiana, entretanto, não parece completa, para o bem das ciências. Uma das ideias que procuramos defender ao longo desta 
dissertação é justamente que os Princípios realmente serviram como "fermento de novos desenvolvimentos ou núcleo de uma nova cristalização" (James, 1912b), e que o behaviorismo de Skinner e o empirismo de James compartilham algo mais além do adjetivo radical. Compartilham, por exemplo, uma atitude em relação à pretensão de suas contribuições à ciência e à filosofia; nas palavras de Skinner (1969, p. 267-268):

O behaviorismo como o conhecemos eventualmente morrerá - não porque é um fracasso mas porque é um sucesso. Como uma filosofia crítica da ciência, necessariamente mudará à medida que uma ciência do comportamento mude e os problemas atuais que definem o behaviorismo possam ser inteiramente resolvidos. A questão básica é a utilidade dos conceitos mentalistas....

Um behaviorismo radical nega a existência de um mundo mental não porque é contencioso ou tem ciúme de um rival, mas porque aqueles que alegam estudar o outro mundo necessariamente falam sobre o mundo do comportamento de maneiras que conflitam com uma análise experimental....

Um behaviorismo radical ataca explicações dualistas do comportamento antes de tudo para esclarecer suas próprias práticas científicas e deve eventualmente fazê-lo a fim de dar sua contribuição para os assuntos humanos....

Formulações científicas não mudam a natureza das coisas formuladas e uma ciência do comportamento não ignora nem destrói os fenômenos associados à introspecção ou qualquer forma de auto-observação. Simplesmente as representa de outras maneiras.

\subsection{Questões para possíveis investigações posteriores}

Nos parágrafos a seguir, gostaríamos de sugerir alguns temas de pesquisa que decorrem dos estudos que realizamos para elaborar esta dissertação e que podem vir a estabelecer melhor as relações entre a psicologia jamesiana e a análise do comportamento, no sentido de confirmá-las ou rejeitá-las, assim como podem talvez servir como objetos de investigação em laboratório ou em campo.

Uma pesquisa de caráter historiográfico poderia mostrar-se um caminho para aprofundar as relações que identificamos entre as teorias de James e Skinner, assim 
como fazer emergir linhas de influência mais evidentes - e mesmo, naturalmente, refutar as ideias que apresentamos ao longo desta dissertação. Uma das questões que julgamos ser uma boa candidata a obter benefícios de uma investigação dos fatos históricos é a presença do adjetivo radical nas filosofias de ambos psicólogos. O empirismo radical seria um dos veios de que se nutriu o behaviorismo radical? Em que medida? Os dois pensadores compartilharam a mesma alma mater; o que e quanto teria significado o trabalho de James no departamento de psicologia da Universidade Harvard em relação ao que Skinner viria a pesquisar e realizar ali, poucas décadas depois?

A historiografia e a comparação de textos também poderia dizer algo sobre o modo como James e Skinner tratavam respectivamente da linguagem e do comportamento verbal. Ambos, por exemplo, usaram como ponto de partida em um número significativo de argumentos a análise das palavras, etimológica ou semântica, para desenvolver suas ideias em psicologia. Por exemplo, James (1890, p. 127-128) versa especificamente sobre a influência do discurso comum na atividade do psicólogo; ao mesmo tempo, a importância que ele dava à linguagem igualmente transparece na riqueza de termos quase barroca com que seu texto nos brinda em muitas passagens para descrever a experiência humana dos indivíduos. No caso de Skinner, textos como "As origens do pensamento cognitivo" (1989), senão todo o livro Comportamento verbal (1957), reforçam o argumento. O estudo sobre escrita automática de Gertrude Stein - que foi aluna de James (Britannica, 2003) e, quem sabe, talvez tenha sido influenciada por ele em seu experimento -, que inspirou Skinner a redigir o artigo “Gertrude Stein tem um segredo?” (1934), poderia ser um elo entre James e Skinner quanto a suas relações com o comportamento verbal?

Antes de enunciar nossa terceira sugestão de pesquisa conforme um método historiográfico, apresentaremos algumas considerações sobre a relação entre o desenvolvimento das ciências e sua utilidade para os seres humanos. Numa passagem instigante sobre o conhecimento científico e o que decorre disso para os interesses humanos, James (1890, p. 865) afirma: 
O mundo da estética e da ética é um mundo ideal, uma utopia, um mundo que as relações exteriores teimam em contradizer, mas que nós tão obstinadamente teimamos em lutar para torná-lo real. Por que então nós de maneira invencível ansiamos por alterar a dada ordem da natureza? Simplesmente porque outras relações entre as coisas são muito mais interessantes para nós e mais encantadoras que as meras taxas de frequência de suas conjunções temporais e espaciais.

Patrono do alinhamento da psicologia nas fileiras das ciências naturais, James ao mesmo tempo posiciona-se como alguém que recusa a mera contemplação dos fatos que as ciências podem reunir; prever e interpretar os fatos psicológicos não é o bastante, há coisas mais interessantes a fazer com eles. De maneira similar, dizia Skinner (1953, p. 14) que a "ciência não está preocupada com a contemplação". O mesmo psicólogo, terminada a Segunda Guerra Mundial, ocupou-se em publicar o manifesto que sintetiza seus anseios por um mundo ideal, em que a ciência cumprisse seu melhor papel a favor dos seres humanos e de uma existência sustentável: Walden II (Skinner, 1948). Outro exemplo importante, dentre vários possíveis e que não foram redigidos sob forma literária, encontra-se em Reflexões sobre behaviorismo e sociedade (Skinner, 1978). Nossa terceira sugestão de pesquisa, assim, é a pergunta: o que é das intenções éticas e estéticas da psicologia científica de James e Skinner, diante da realidade atual? A fim de responder a essa questão, seria possível estabelecer como um contexto de comparação os fatos e análises apresentados por Sevcenko (2001) a respeito da história das ciências naturais na modernidade, da aplicação acelerada da técnica delas derivada a partir da segunda metade do século 19 e dos ciclos estonteantes de transformação tecnológica na sociedade a partir do desenvolvimento dos computadores na década de 1950. Talvez seja possível, ainda, usar o procedimento que esse mesmo autor aplicou para esclarecer as relações entre literatura e transformação da sociedade na vida e obra de Lima Barreto e Euclides da Cunha (Sevcenko, 2003).

Quanto às questões que poderiam ser investigadas em laboratório ou em campo, cremos que a tradução da teoria do eu em referências a contingências de reforço, esboçada no capítulo 4 desta dissertação, aponta alguns caminhos para a imaginação dos experimentadores. Buscar a elucidação das variáveis que 
determinam a consciência do indivíduo como um eu a partir de seu próprio ponto de vista, ou seja, a partir do que se costuma denominar subjetividade, é útil em várias aplicações da análise do comportamento, ou de uma psicologia fundamentada na filosofia do behaviorismo radical. No campo da psicoterapia, digamos, talvez seja possível experimentar técnicas de intervenção terapêutica em situações como de crise de identidade ou despersonalização, por exemplo, baseadas no controle de esquemas de reforço a que o paciente está submetido, identificados a partir dos elementos que James descreveu como constituintes do eu e interpretáveis em termos de contingências ambientais. Experimentos cujo objetivo é pesquisar aquelas variáveis poderiam ser baseados nos delineamentos usados para investigar o comportamento individual em microssociedades (H. H. Emurian, C. S. Emurian, Bigelow \& Brady, 1976; H. H. Emurian, C. S. Emurian \& Brady, 1978, 1985) ou mesmo em que o sujeito está sozinho num ambiente isolado (Bernstein \& Ebbesen, 1978). 


\section{REFERÊNCIAS}

Abib, J. A. D. (1996). Revoluções psicológicas: um retorno a Wilhelm Wundt, William James e outros clássicos. Cadernos de História e Filosofia da Ciência 6(1), 107-143.

Abib, J. A. D. (1999). Empirismo radical e subjetividade. Psicologia: Teoria e Pesquisa 15(1), 55-63.

Ades, C. (1997). O morcego, outros bichos e a questão da consciência animal. Psicologia USP 8(2), 129-158.

Balzac, H. (1834/1954). O pai Goriot (Gomes da Silveira, trad.; Col. A Biblioteca dos Séculos: A comédia humana, vol. 4). Porto Alegre: Globo.

Barnes-Holmes, D. (2003). For the radical behaviorist biological events are not biological and public events are not public. Behavior and Philosophy 31, 145-150.

Baum, W. M. (2006). Compreender o behaviorismo: comportamento, cultura e evolução (M. T. A. Silva, M. A. Matos, G. Y. Tomanari, E. Z. Tourinho, trads.; $2^{\mathrm{a}}$ ed. rev. e ampl.). Porto Alegre: ArtMed.

Bernstein, D. J. \& Ebbesen, E. B. (1978). Reinforcement and substitution in humans: a multiple-response analysis. Journal of the Experimental Analysis of Behavior 30(3), 243-253.

Britannica. (2003). Stein, Gertrude / Thorndike, Edward L. In Encyclopaedia Britannica 2003 Deluxe Edition CD-ROM. Chicago: Encyclopaedia Britannica.

Camus, A. (1942/1989). O mito de Sísifo: ensaio sobre o absurdo (M. Gama, trad.; $3^{\mathrm{a}}$ ed.). Rio de Janeiro: Guanabara.

Carone, I. (2004). Metáfora e psicologia: uma relação perigosa? Cadernos de Estudos e Pesquisas 10(1-007/04), 1-34. São Paulo: Universidade Paulista.

Castiglioni, L. \& Mariotti, S. (1966/1985). Vocabolario della lingua latina. Turim: Loescher.

Dawkins, R. (2006). The God delusion. Londres: Bantam.

Dennett, D. C. (2005). Sweet dreams: philosophical obstacles to a science of consciousness. Cambridge, MA: MIT Press.

Einstein, A. (1905). On the electrodynamics of moving bodies. Recuperado em 10 de julho, 2007, de http:/ / www.fourmilab.ch/etexts/einstein/specrel/specrel.pdf 
Emurian, H. H., Emurian, C. S., Bigelow, G. E. \& Brady, J. V. (1976). The effects of a cooperation contingency on behavior in a continuous three-person environment. Journal of the Experimental Analysis of Behavior 25(3), 293-302.

Emurian, H. H., Emurian, C. S. \& Brady, J. V. (1978). Effects of a pairing contingency on behavior in a three-person programmed environment. Journal of the Experimental Analysis of Behavior 29(2), 319-329.

Emurian, H. H., Emurian, C. S. \& Brady, J. V. (1985). Positive and negative reinforcement effects on behavior in a three-person microsociety. Journal of the Experimental Analysis of Behavior 44(2), 157-174.

Everett, D. L. (2005). Cultural constraints on grammar and cognition in pirahã. Current Anthropology 46(4), 621-646.

Figueiredo, L. C. M. (1991). Matrizes do pensamento psicológico. Petrópolis, RJ: Vozes.

Figueiredo, L. C. M. (1992). A invenção do psicológico: quatro séculos de subjetivação: 1500-1900 (Col. Linhas de Fuga). São Paulo: Educ / Escuta.

Gledson, J. (2003). Influências e impasses: Drummond e alguns contemporâneos (F. Dentello, trad.). São Paulo: Companhia das Letras.

James, W. (1880/1947). Great men, great thoughts, and the environment. In Selected papers on philosophy (C. M. Bakewell, intr.; Everyman's Library, n. 739; p. 165197). Londres / Nova York: J. M. Dent / E. P. Dutton.

James, W. (1890/1994). The principles of psychology (Great Books of the Western World, vol. 53). Chicago: Encyclopaedia Britannica.

James, W. (1912a). Does "consciousness" exist? Recuperado em 14 de julho, 2009, de http://ebooks.adelaide.edu.au/j/james/william/radical/chapter1.html

James, W. (1912b). A world of pure experience. Recuperado em 14 de julho, 2009, de http://ebooks.adelaide.edu.au/j/james/william/radical/chapter2.html

Kuhn, T. S. (1970). The structure of scientific revolutions (2 ${ }^{\text {nd }}$ ed. enl.). Chicago: University of Chicago Press.

Lispector, C. (1977/1999). A hora da estrela. Rio de Janeiro: Rocco.

Machado de Assis, J. M. (1881/1981). Memórias póstumas de Brás Cubas (8a ed.; Série Bom Livro). São Paulo: Ática.

Machado de Assis, J. M. (1891/1980). Quincas Borba (4ª ed.; Série Bom Livro). São Paulo: Ática. 
Malone Jr., J. C. (1975). William James and B. F. Skinner: behaviorism, reinforcement, and interest. Behaviorism 3(2), 140-151.

Mechner, F. (2008). An invitation to behavior analysts: review of In search of memory: the emergence of a new science of mind by Eric R. Kandel. Journal of the Experimental Analysis of Behavior 90(2), 235-248.

Neuringer, A., Jensen, G. \& Piff, P. (2007). Stochastic matching and the voluntary nature of choice. Journal of the Experimental Analysis of Behavior 88(1), 1-28.

Northoff, G. \& Panksepp, J. (2008). The trans-species concept of self and the subcortical-cortical midline system. Trends in Cognitive Sciences 12(7), 259-264.

Proust, M. (1913/1997). No caminho de Swann (M. Quintana, trad.; 18 ed.). São Paulo: Globo.

Ribeiro, F. J. L. (1997). Quimeras, centauros e a questão da consciência animal: comentário a respeito do artigo de César Ades. Psicologia USP 8(2), 159-164.

Sevcenko, N. (2001). A corrida para o século XXI: no loop da montanha-russa (C. Carletti, pesq. icon.; Col. Virando Séculos, vol. 7). São Paulo: Companhia das Letras.

Sevcenko, N. (2003). Literatura como missão: tensões sociais e criação cultural na Primeira República (2 $2^{\mathrm{a}}$ ed. rev. e ampl.). São Paulo: Companhia das Letras.

Silva, M. T. A., Gonçalves, F. L. \& Garcia-Mijares, M. (2007). Neural events in the reinforcement contingency. The Behavior Analyst 30(1), 17-30.

Skinner, B. F. (1931/1999). The concept of the reflex in the description of behavior. In Cumulative record: definitive edition (p. 475-503). Acton, MA: Copley.

Skinner, B. F. (1934/1999). Has Gertrude Stein a secret? In Cumulative record: definitive edition (p. 405-415). Acton, MA: Copley.

Skinner, B. F. (1945/1999). The operational analysis of psychological terms. In Cumulative record: definitive edition (p. 416-430). Acton, MA: Copley.

Skinner, B. F. (1948). Walden two. Nova York: Macmillan.

Skinner, B. F. (1953/1967). Science and human behavior. Nova York: The Free Press.

Skinner, B. F. (1957/1992). Verbal behavior. Acton, MA: Copley.

Skinner, B. F. (1959). John Broadus Watson, behaviorist. Science 129, 197-198. 
Skinner, B. F. (1963/1999). Reflections on a decade of teaching machines. In Cumulative record: definitive edition (p. 240-253). Acton, MA: Copley.

Skinner, B. F. (1966/1999). Some responses to the stimulus "Pavlov". In Cumulative record: definitive edition (p. 648-652). Acton, MA: Copley.

Skinner, B. F. (1969). Contingencies of reinforcement: a theoretical analysis (The Century Psychology Series). Nova York: Appleton-Century-Crofts.

Skinner, B. F. (1974). About behaviorism. Nova York: Alfred A. Knopf.

Skinner, B. F. (1978). Reflections on behaviorism and society (Century Psychology Series). Englewood Cliffs, NJ: Prentice-Hall.

Skinner, B. F. (1980). Notebooks (R. Epstein, ed. \& intr.). Englewood Cliffs, NJ: Prentice-Hall.

Skinner, B. F. (1986). The evolution of verbal behavior. Journal of the Experimental Analysis of Behavior 45(1), 115-122.

Skinner, B. F. (1989). The origins of cognitive thought. American Psychologist 44(1), 1318.

Skinner, B. F. (1990). Can Psychology be a science of mind? American Psychologist 45(11), 1206-1210.

Tourinho, E. Z. (2006). Subjetividade e relações comportamentais. Tese para concurso de professor titular, Centro de Filosofia e Ciências Humanas, Universidade Federal do Pará, Belém.

Turing, A. M. (1950). Computing machinery and intelligence. Mind 59(236), 433-460.

Whitehead, A. N. (1925/1997). Science and the modern world. Nova York: The Free Press. 